\title{
Article \\ CYP1A2 mRNA Expression Rather than Genetic Variants Indicate Hepatic CYP1A2 Activity
}

\author{
Ferenc Fekete ${ }^{1,2}$, Katalin Mangó ${ }^{1}$, Annamária Minus ${ }^{1}$, Katalin Tóth ${ }^{1}$ and Katalin Monostory ${ }^{1, *(D)}$ \\ 1 Institute of Enzymology, Research Centre for Natural Sciences, Magyar Tudósok 2, \\ H-1117 Budapest, Hungary; fekete.ferenc@ttk.hu (F.F.); mango.katalin@ttk.hu (K.M.); \\ minus.annamaria@ttk.hu (A.M.); tubakati@gmail.com (K.T.) \\ 2 Doctoral School of Biology and Institute of Biology, Eötvös Loránd University, Pázmány Péter Sétány 1/A, \\ H-1117 Budapest, Hungary \\ * Correspondence: monostory.katalin@ttk.hu
}

check for updates

Citation: Fekete, F.; Mangó, K.; Minus, A.; Tóth, K.; Monostory, K. CYP1A2 mRNA Expression Rather than Genetic Variants Indicate Hepatic CYP1A2 Activity. Pharmaceutics 2022, 14, 532. https://doi.org/10.3390/ pharmaceutics14030532

Academic Editors: Francisco Abad Santos and Pablo Zubiaur

Received: 14 January 2022

Accepted: 23 February 2022

Published: 27 February 2022

Publisher's Note: MDPI stays neutral with regard to jurisdictional claims in published maps and institutional affiliations.

Copyright: (c) 2022 by the authors. Licensee MDPI, Basel, Switzerland. This article is an open access article distributed under the terms and conditions of the Creative Commons Attribution (CC BY) license (https:// creativecommons.org/licenses/by/ $4.0 /)$.

\begin{abstract}
CYP1A2, one of the most abundant hepatic cytochrome P450 enzymes, is involved in metabolism of several drugs and carcinogenic compounds. Data on the significance of CYP1A2 genetic polymorphisms in enzyme activity are highly inconsistent; therefore, the impact of CYP1A2 genetic variants $(-3860 \mathrm{G}>\mathrm{A},-2467 \mathrm{delT},-739 \mathrm{~T}>\mathrm{G},-163 \mathrm{C}>\mathrm{A}, 2159 \mathrm{G}>\mathrm{A})$ on mRNA expression and phenacetin $O$-dealkylation selective for CYP1A2 was investigated in human liver tissues and in psychiatric patients belonging to Caucasian populations. CYP1A2* $1 F$, considered to be associated with high CYP1A2 inducibility, is generally identified by the presence of $-163 \mathrm{C}>\mathrm{A}$ polymorphism; however, we demonstrated that $-163 \mathrm{C}>\mathrm{A}$ existed in several haplotypes (CYP1A2*1F, CYP1A2*1L, CYP1A2*1M, CYP1A2*1V, CYP1A2*1W), and consequently, CYP1A2*1F was a much rarer allelic variant $(0.4 \%)$ than reported in Caucasian populations. Of note, $-163 \mathrm{C}>\mathrm{A}$ polymorphism was found to result in an increase of neither mRNA nor the activity of CYP1A2. Moreover, hepatic CYP1A2 activity was associated with hepatic or leukocyte mRNA expression rather than genetic polymorphisms of CYP1A2. Consideration of non-genetic phenoconverting factors (co-medication with CYP1A2-specific inhibitors/inducers, tobacco smoking and non-specific factors, including amoxicillin+clavulanic acid therapy or chronic alcohol consumption) did not much improve genotypephenotype estimation. In conclusion, CYP1A2-genotyping is inappropriate for the prediction of CYP1A2 function; however, CYP1A2 mRNA expression in leukocytes can inform about patients' CYP1A2-metabolizing capacity.
\end{abstract}

Keywords: CYP1A2; phenacetin O-dealkylation activity; CYP1A2 expression; CYP1A2 genetic polymorphisms; non-genetic factors; smoking; chronic alcohol consumption; amoxicillin+clavulanic acid; ciprofloxacin; carbamazepine

\section{Introduction}

CYP1A2, one of the most abundant drug-metabolizing cytochrome P450 (CYP) enzymes in the human liver, is involved in phase I biotransformation processes. Its relative amount in hepatic microsomes is approximately $13-15 \%$ of the total CYP pool [1], and it is scarcely expressed in extrahepatic tissues. Sporadic reports have, however, cited CYP1A2 expression in leukocytes, the colon and rectum $[2,3]$ as well as in the lung, where CYP1A2 mRNA and enzyme protein have been detected at a low level [4]. CYP1A2 catalyzes the metabolism of several clinically important drugs (e.g., olanzapine, clozapine, duloxetine, lidocaine, theophylline, caffeine and tacrine) and endogenous molecules (e.g., retinoids, $17 \beta$-estradiol, estrone, melatonin, uroporphyrinogen and arachidonic acid). It is also involved in the bioactivation of procarcinogenic compounds (e.g., polycyclic aromatic hydrocarbons and heterocyclic aromatic amines) and mycotoxins (e.g., aflatoxin B1) [5,6].

The CYP1A2 gene is located on chromosome 15 in a head-to-head orientation with CYP1A1 and consists of seven exons and six introns with a non-coding region in exon 1. 
The regulatory region of CYP1A2 overlaps with that of the CYP1A1 gene; therefore, some common characteristics have been recognized in transcriptional regulation of CYP1A2 and CYP1A1 [7-9]. Both the CYP1A2 and CYP1A1 enzymes are highly inducible, and the common promoter region contains several copies of regulatory elements and transcription factor binding sites, such as the xenobiotic responsive element (XRE) [6,10]. Activation of the aromatic hydrocarbon receptor (AhR) by xenobiotics (e.g., omeprazole, aromatic hydrocarbons, components of tobacco smoke and charcoaled meat) is involved in transcriptional induction of CYP1A genes [11]. The ligand-activated AhR forms a heterodimer with the AhR nuclear translocator (ARNT), and this transcriptional activator complex interacts with the XRE in the regulatory region to initiate transcription of CYP1A genes. Furthermore, several endogenous factors, both genetic and non-genetic, have been reported to contribute to the large inter-individual differences observed in CYP1A2 mRNA expression and activity [1,11-13].

The variability in CYP1A2 activity is often explained by CYP1A2 genetic polymorphisms. CYP1A2 allelic variants contain one or more single nucleotide polymorphisms (SNPs), and, further, a particular SNP can be present in several haplotypes, which makes the identification of allelic variants laborious [14]. To date, more than 40 CYP1A2 alleles and haplotypes have been listed by PharmVar (Pharmacogene Variation Consortium), which attributes increased inducibility or decreased expression to several of these alleles (https://www.pharmvar.org/gene/CYP1A2, access date: 12 January 2022). The most frequently studied CYP1A2 SNP is the $-163 \mathrm{C}>\mathrm{A}$ nucleotide change (rs762551) in intron 1, generally designated as $C Y P 1 A 2 * 1 F$. $C Y P 1 A 2 * 1 F$ has been suggested to be associated with increased inducibility observed in smokers or in subjects treated with the CYP1A2 inducer omeprazole; however, the contribution of $-163 \mathrm{C}>\mathrm{A}$ to CYP1A2 activity was recognized as inconsistent in the literature [15-21]. Most studies considered CYP1A2*1F to be identical to $-163 \mathrm{C}>\mathrm{A}$; however, $-163 \mathrm{C}>\mathrm{A}$ is also part of other haplotypes $\left(C Y P 1 A 2^{*} 1 J\right.$, CYP1A2*1K, CYP1A2*1L, CYP1A2*1M, CYP1A2*1V and CYP1A2*1W) [22,23]. Due to the strong linkage disequilibrium between various CYP1A2 polymorphisms, such as -163C >A (rs762551), -3860G>A (rs2069514), -2467delT (rs35694136), -739T>G (rs20695) and 2159G $>$ A (rs2472304), the functional relevance of a particular SNP in CYP1A2 activity may differ from that of the haplotype(s). The -3860G >A (rs2069514) polymorphism identified in CYP1A2*1C has been reported to be associated with decreased metabolism of the CYP1A2 probe substrate caffeine [16,24], and, similarly, the decreased CYP1A2 activity was attributed to the -2467 delT (rs35694136) polymorphism in CYP1A2*1D [16]. However, the increased CYP1A2 inducibility in smokers carrying -163C $>$ A appeared to be reversed in those subjects with $C Y P 1 A 2^{*} 1 L$, where $-163 C>A$ exists in linkage disequilibrium with $-3860 \mathrm{G}>\mathrm{A}$ and -2467 delT $[16,20]$. Furthermore, the increased inducibility due to the $-163 \mathrm{C}>\mathrm{A}$ polymorphism has been demonstrated to be abolished by the linkage disequilibrium with -2467 delT in subjects that carry CYP1A2* $1 \mathrm{~V}$ or CYP1A2* $1 \mathrm{~W}$ [20]. The $-163 \mathrm{C}>\mathrm{A}$ polymorphism often occurs in linkage disequilibrium with 2159G $>$ A (rs2472304) in CYP1A2*1M; however, the 2159G >A nucleotide change has been reported to have no effect on caffeine metabolism [25]. CYP1A2*1K, which is identified by the haplotype with three polymorphisms, -163C >A (rs762551), -739T>G (rs20695) and -729C>T (rs12720461), has been reported to display reduced CYP1A2 activity, which was primarily attributed to the $-729 \mathrm{C}>\mathrm{T}$ polymorphism affecting a putative transcription factor binding site [26]. In addition to CYP1A2 genetic variability, significant interethnic variation in the CYP1A2 allele and haplotype frequencies has been demonstrated [14], and, due to misinterpretation of the haplotypes from SNP data, some inconsistency in frequency estimation in various populations was recognized, further complicating the evaluation of phenotype consequences.

Genetic polymorphisms seem to explain only $25-33 \%$ of inter-individual variation in CYP1A2 activity and expression, and non-genetic factors (e.g., sex, age, nutrition, diseases, hormonal status, smoking and medication) that regulate CYP1A2 gene expression or inhibit enzyme function may also contribute to the inter-individual variability of the CYP1A2 phenotype to some extent $[10,27,28]$. It has been indicated that hepatic CYP1A2 expression 
and activity was influenced by gender and age as intrinsic non-genetic factors [29,30]; however, a current study did not confirm the sex- and age-related differences in CYP1A2 function [31]. Clear evidence for the AhR-mediated induction of CYP1A2 transcription by omeprazole, components of tobacco smoke or consumption of broccoli and brussels sprout has been provided [20,32,33], whereas indirect mechanisms, which up- and downregulate nuclear receptors and transcription factors, have also been suggested to modify CYP1A2 expression [11]. Furthermore, medication with well-known CYP1A2 inhibitors, such as ciprofloxacin, fluvoxamine and oral contraceptives, has been demonstrated to substantially reduce CYP1A2 activity [34-36]. Therefore, investigation of both genetic and non-genetic factors is required for appropriate estimation of CYP1A2-mediated metabolism. The main aim of the present study was to evaluate the influence of CYP1A2 polymorphisms on CYP1A2 activity and mRNA expression in human liver samples and in patients with psychiatric disorders. The hepatic microsomal CYP1A2 activity was characterized by using phenacetin as the CYP1A2-selective probe substrate [10]. Furthermore, we aimed to identify non-genetic factors (demographic parameters, medication, smoking and alcohol consumption) that can potentially modify CYP1A2 expression and/or activity; thus, a more complex picture was expected to be obtained about the major determinants of CYP1A2 expression and function.

\section{Materials and Methods}

Human liver tissues $(\mathrm{N}=151)$ were obtained from organ transplant donors at the Department of Transplantation and Surgery, Semmelweis University (Budapest, Hungary). Human livers not selected for transplantation or liver tissues remaining after reduced-size transplantation were used in the present study. Furthermore, 274 unrelated inpatients at the Department of Psychiatry and Psychotherapy (Semmelweis University) were involved in the study. All subjects were 18 years of age or older. The demographic data and clinical histories of the liver tissue donors and patients with psychiatric disorders were recorded (Table 1).

Table 1. Clinical history of the human subjects.

\begin{tabular}{|c|c|c|c|c|}
\hline & \multicolumn{2}{|l|}{ Liver Tissue Donors } & Psychiatric Patients & \\
\hline Number of subjects & 151 & & 274 & \\
\hline Age (year) ${ }^{1}$ & $46(18 ; 74)$ & & $39(18 ; 76)$ & \\
\hline Gender (male/female) & $82 / 69$ & & $110 / 164$ & \\
\hline \multicolumn{2}{|c|}{ Cause of death } & & Psychiatric disorders & \\
\hline \multirow[b]{6}{*}{ Cerebral hemorrhage/hematoma } & Car/motor/bike accident & 14 & Schizophrenia & 140 \\
\hline & Anoxic cerebral injury/asphyxia & 5 & Persistent delusional disorders & 2 \\
\hline & Seizure induced cerebral injury & 3 & Acute and transient psychotic disorders & 16 \\
\hline & Suicide & 4 & Schizoaffective disorders & 44 \\
\hline & Unknown cerebral injury & 9 & Other non-organic psychotic disorders & 2 \\
\hline & Ruptured cerebral aneurysm & 4 & Bipolar affective disorder & 52 \\
\hline & Epidural hematoma & 1 & Depressive episode & 5 \\
\hline & Intraventricular hemorrhage & 8 & Recurrent depressive disorder & 3 \\
\hline & Subarachnoid hemorrhage & 31 & Other anxiety disorders & 1 \\
\hline & Subdural hemorrhage & 8 & Specific personality disorders & 2 \\
\hline & Unknown cerebral hemorrhage & 15 & Unknown & 7 \\
\hline \multirow[t]{2}{*}{ Stroke } & Ischemic stroke & 7 & & \\
\hline & Hemorrhagic stroke & 2 & & \\
\hline Tumor & & 36 & & \\
\hline Unknown & & 4 & & \\
\hline \multicolumn{5}{|l|}{ Non-genetic factors } \\
\hline Amoxicillin+clavulanic acid therapy & 8 & & 0 & \\
\hline Chronic alcohol consumption & 19 & & 0 & \\
\hline Medication with CYP1A2 inducer & 0 & & 6 & \\
\hline Medication with CYP1A2 inhibitor & 1 & & 0 & \\
\hline Smoking & 8 & & 96 & \\
\hline
\end{tabular}

\subsection{Human Liver Microsomes and RNA Samples}

Human liver tissues were perfused with Euro-Collins solution (Fresenius AG, Bad Homburg vdH, Germany) and excised. For isolation of the microsomal fraction, the tissues were homogenized in $0.1 \mathrm{M}$ Tris- $\mathrm{HCl}$ buffer ( $\mathrm{pH}$ 7.4) containing $1 \mathrm{mM}$ EDTA and $154 \mathrm{mM}$ $\mathrm{KCl}$, and differential centrifugation was performed as described by van der Hoeven and 
Coon [37]. Microsomal protein content was determined by the method of Lowry et al. using bovine serum albumin as the standard [38]. Total RNA was extracted from the liver tissues (approximately $50 \mathrm{mg}$ ), and from leukocytes (approximately $10^{7}$ cells) isolated from peripheral blood samples using TRIzol reagent (Invitrogen, Carlsbad, CA, USA), according to the manufacturer's instructions. The RNA samples were stored in ultra-pure water containing $0.1 \%$ diethylpyrocarbonate at $-80{ }^{\circ} \mathrm{C}$ for further analyses.

\subsection{CYP1A2 Enzyme Assay}

The method of Butler et al. was followed to determine the hepatic phenacetin O-dealkylation activity selective for CYP1A2 [39]. The incubation mixture contained a NADPH-generating system (1 mM NADP, $10 \mathrm{mM}$ glucose 6-phosphate, $5 \mathrm{mM} \mathrm{MgCl}_{2}$ and 2 units $/ \mathrm{mL}$ glucose 6-phosphate dehydrogenase), human liver microsomes $(1 \mathrm{mg} / \mathrm{mL})$ and phenacetin $(200 \mu \mathrm{M})$. After a 20-min incubation period, the reaction was terminated by ice-cold methanol, and the incubation mixture was centrifuged for $10 \mathrm{~min}$ at $10,000 \times g$. The metabolite (acetaminophen) formation was determined by a high-performance liquid chromatographic analysis, using Inertsil ODS-4 column $(75 \times 2.1 \mathrm{~mm}, 3 \mu \mathrm{m}$; GL Sciences Inc., Tokyo, Japan) and a mobile phase containing 30\% acetonitrile and $0.1 \%$ formic acid [39]. A CYP1A2 enzyme assay for each donor was performed in triplicate, and the activity was expressed as pmol acetaminophen/(mg protein $* \min )$.

\subsection{CYP1A2 Genotyping}

Genomic DNA was isolated from the liver tissues and peripheral blood samples by Quick-DNA ${ }^{\mathrm{TM}}$ Universal Kit (Zymo Research, Irvine, CA, USA). Hydrolysis SNP analyses for -3860G >A (rs2069514), -2467delT (rs35694136), -739T >G (rs206926), -163C >A (rs762551) and 2159G >A (rs2472304) were performed by a polymerase chain reaction (PCR) with commercially available (Thermo Fisher Scientific, Waltham, MA, USA) or self-designed TaqMan assays (Supplementary Table S1). Real-time PCR was carried out with $30 \mathrm{ng}$ of genomic DNA by using Luminaris Color Probe qPCR Master Mix (Thermo Fisher Scientific). The incubation protocol was as follows: $50^{\circ} \mathrm{C}$ for $2 \mathrm{~min}, 95^{\circ} \mathrm{C}$ for $10 \mathrm{~min}$ and 35 cycles of $95^{\circ} \mathrm{C}$ for $15 \mathrm{~s}, 61^{\circ} \mathrm{C}$ for $1 \mathrm{~min}$.

\subsection{Analysis of CYP1A2 mRNA Levels by Quantitative Real-Time PCR}

Total RNA ( $3 \mu \mathrm{g})$ was reverse-transcribed into single-stranded cDNA by using Maxima First Strand cDNA Synthesis Kit (Thermo Fisher Scientific, Waltham, MA, USA). The real-time PCR with human CDNA was performed by using KAPA Fast Probes Mastermix (KAPA Biosystems, Cape Town, South Africa) and TaqMan probes for CYP1A2 (Bio-Search Technologies, Novato, CA, USA). The incubation protocol was $95^{\circ} \mathrm{C}$ for 3 min and 45 cycles of $95^{\circ} \mathrm{C}$ for $3 \mathrm{~s}, 58^{\circ} \mathrm{C}$ for $30 \mathrm{~s}$. The quantity of the target mRNA relative to that of the housekeeping gene glyceraldehyde 3-phosphate dehydrogenase (GAPDH) was determined. GAPDH expression was set to 1, and CYP1A2 mRNA levels were normalized by the GAPDH expression. The sequences of primers and probes used for the real-time PCR analyses of CYP1A2 and the GAPDH expression were previously reported by Déri et al. [40].

\subsection{Statistical Analysis}

For liver tissue donors $(\mathrm{N}=151)$ and psychiatric patients $(\mathrm{N}=274), C Y P 1 A 2$ genotypes (for CYP1A2*1C, CYP1A2*1D, CYP1A2*1E, CYP1A2*1F, CYP1A2*1L, CYP1A2*1M, CYP1A2* $1 V$ and CYP1A2*1W) were determined. Hepatic CYP1A2 activities $(\mathrm{N}=131)$ and/or the mRNA expression ( $\mathrm{N}=93)$ of CYP1A2, as well as the CYP1A2 expression in leukocytes (tissue donors $\mathrm{N}=35$; psychiatric patients $\mathrm{N}=274$ ) were also determined. For reconstructing the CYP1A2 haplotypes from the SNP data based on a Markov chain Monte Carlo algorithm, we used PHASE software (v2.1; Department of Statistics, University of Washington, Seattle) [41,42]. The frequency distribution of CYP1A2 activities was determined in 131 liver tissue donors, and three categories (low, intermediate, high) were distinguished for poor, intermediate and normal metabolizers. The comparison of 
CYP1A2 enzyme activities or mRNA levels between various groups (CYP1A2 genotype or phenotype groups or even gender-age groups) was performed by Kruskal-Wallis ANOVA followed by Dunn's multiple comparisons test (GraphPad Instat v3.05; GraphPad Software, San Diego, CA, USA). Phenoconversion frequencies were evaluated on the basis of the nongenetic factor frequencies (medications, chronic alcohol consumption and smoking) in the medical histories of tissue donors in various genotype-based phenotype groups by Fisher's exact test. Linear regression models (Supplementary Table S2) were formulated to test potential associations between CYP1A2 activity $(\mathrm{N}=131)$ or mRNA expression $(\mathrm{N}=93)$ as dependent variables and CYP1A2 SNPs, haplotypes, sex, age (under 50 and above 50 years old), chronic alcohol consumption and medication with amoxicillin+clavulanic acid as covariates. Multiple linear regression analyses were carried out by IBM SPSS Statistics software [v28.0.1.0 (142), IBM Corp., Armonk, NY, USA]. A $p$ value of $<0.05$ was considered to be statistically significant.

\section{Results}

\subsection{CYP1A2 Haplotypes and Genotypes of Liver Tissue Donors and Psychiatric Patients}

The CYP1A2 SNPs most common in Caucasian populations $(-3860 \mathrm{G}>\mathrm{A},-2467 \mathrm{delT}$, $-739 \mathrm{~T}>\mathrm{G},-163 \mathrm{C}>\mathrm{A}$ and $2159 \mathrm{G}>\mathrm{A}$ ) were identified in 151 liver tissue donors and in $274 \mathrm{pa}-$ tients with psychiatric disorders. Those subjects who did not carry any of the investigated polymorphisms were considered to have the $C Y P 1 A 2^{*} 1$ wild-type allele. The relative frequencies of the CYP1A2 haplotypes and genotypes in the liver tissue donors and patients with psychiatric disorders were compared to those reported in Caucasian populations (Table 2) $[20,25,43,44]$. The frequency of the wild-type CYP1A2*1, often designated as CYP1A2 ${ }^{*} 1 A(32.8 \%$ and $32.1 \%)$, was similar to that was reported in Caucasians [20,25,43]. Although the liver tissue donors and psychiatric patients all belonged to Caucasian populations, the frequencies of several $C Y P 1 A 2$ haplotypes markedly differed from that of the previously reported frequency data in Caucasians. The CYP1A2* $1 C, C Y P 1 A 2 * 1 D$ and CYP1A2* $1 E$ alleles were identified in $0.4-4 \%, 3.4-11 \%$ and $0.4-6 \%$ of the Caucasian populations [44]; however, these alleles were detected neither in the tissue donors nor in the patients with psychiatric disorders. The CYP1A2 polymorphisms of $-3860 \mathrm{G}>\mathrm{A},-2467 \mathrm{delT}$ or $-739 \mathrm{~T}>\mathrm{G}$ were identified in these subjects, but they were always in linkage disequilibrium with other SNPs, e.g., with $-163 \mathrm{C}>\mathrm{A}$. The CYP1A2*1F carrying $-163 \mathrm{C}>\mathrm{A}$ was found to be one of the rarest alleles, detected only in the psychiatric group with a frequency of $0.4 \%$, which was significantly lower than the frequency of $32-57 \%$ reported previously in the literature [44]. This was attributed to the linkage disequilibrium of $-163 \mathrm{C}>\mathrm{A}$ with other CYP1A2 SNPs, most frequently with $2159 \mathrm{G}>\mathrm{A}$ in $C Y P 1 A 2^{*} 1 M$. In the liver tissue donors and psychiatric patients, the most prevalent allele was $C Y P 1 A 2 * 1 M$, at the frequencies of $59.9 \%$ and $62.6 \%$, respectively, which was somewhat higher than what was observed by Djordjevic et al. in the Serbian population (54.8\%) [25]. The CYP1A2* $1 L, C Y P 1 A 2 * 1 V$ and CYP1A2* $1 W$ alleles were less common than $C Y P 1 A 2^{*} 1 M$ in both the investigated groups $\left(C Y P 1 A 2^{*} 1 L\right.$ allele: $2 \%$ and $1.1 \%$; $C Y P 1 A 2 * 1 V: 3.6 \%$ and $2.7 \%$; and $C Y P 1 A 2 * 1 W: 1.7 \%$ and $1.1 \%$ in liver tissue donors and in psychiatric patients), similar to other Caucasian populations [20].

More than one tenth of the tissue donors and psychiatric patients carried none of the CYP1A2 SNPs (12.6\% and $12.8 \%$, respectively) and were considered to be a CYP1A2* $1{ }^{*} 1$ carrier, whereas nearly $40 \%$ of the subjects were heterozygous $C Y P 1 A 2 * 1 / m u t$ with the highest proportion of the $C Y P 1 A 2^{*} 1 /{ }^{*} 1 M$ genotype (35.8\% of the liver tissue donors and $35 \%$ of the psychiatric patients). The $C Y P 1 A 2^{*} 1 /{ }^{*} 1 F$ genotype was identified only among the psychiatric patients in 2 of the 274 subjects. The proportions of $C Y P 1 A 2{ }^{*} 1{ }^{*} 1 \mathrm{~V}(2 \%$ and $1.8 \%)$ and $C Y P 1 A 2^{*} 1 /{ }^{*} 1 W(1.3 \%$ and $1.1 \%)$ genotypes in the liver tissue donors and in the psychiatric patients, respectively, were similar. Individuals with $C Y P 1 A 2^{*} 1{ }^{*} 1 L$ genotype occurred only among the liver tissue donors ( 2 of 151 subjects). Nearly half of the subjects ( $47 \%$ of the liver tissue donors and $48.7 \%$ of psychiatric patients) were found to have a CYP1A2mut/mut genotype. The most common CYP1A2mut/mut genotype was CYP1A2 ${ }^{*} 1 M /{ }^{*} 1 M$ (37.1\% of liver tissue donors and $42.7 \%$ of psychiatric patients), whereas 
the CYP1A2* $1 M /{ }^{*} 1 L, C Y P 1 A 2 * 1 M /{ }^{*} 1 V, C Y P 1 A 2 * 1 M /{ }^{*} 1 W, C Y P 1 A 2 * 1 V /{ }^{*} 1 L, C Y P 1 A 2 * 1 V /{ }^{*} 1 V$ and $C Y P 1 A 2 * 1 W /{ }^{*} 1 L$ genotypes were much less prevalent (Table 2$)$.

Table 2. CYP1A2 allele and genotype frequencies in the tissue donors, psychiatric patients and in Caucasian populations.

\begin{tabular}{|c|c|c|c|c|c|c|}
\hline \multirow[t]{2}{*}{ CYP1A2 Allele } & \multirow[t]{2}{*}{ Nucleotide Changes } & \multicolumn{2}{|c|}{$\mathbf{N}$} & \multicolumn{3}{|c|}{ Frequency (\%) } \\
\hline & & Tissue donors & $\begin{array}{l}\text { Psychiatric } \\
\text { patients }\end{array}$ & Tissue donors & Psychiatric patients & $\begin{array}{c}\text { Caucasian } \\
\text { populations }\end{array}$ \\
\hline${ }^{*} 1^{2}$ & None & 99 & 176 & 32.8 & 32.1 & $24.4-63.5$ \\
\hline${ }^{*} 1 C$ & $-3860 \mathrm{G}>\mathrm{A}$ & 0 & 0 & 0 & 0 & $0.4-4$ \\
\hline${ }^{*} 1 D$ & -2467 delT & 0 & 0 & 0 & 0 & $3.4-11$ \\
\hline${ }^{*} 1 E$ & $-739 \mathrm{~T}>\mathrm{G}$ & 0 & 0 & 0 & 0 & $0.4-6$ \\
\hline${ }^{*} 1 F$ & $-163 C>A$ & 0 & 2 & 0 & 0.4 & $32-57$ \\
\hline${ }^{*} 1 L$ & $\begin{array}{c}-3860 \mathrm{G}>\mathrm{A} ;-2467 \mathrm{delT} \\
-163 \mathrm{C}>\mathrm{A} ; 5347 \mathrm{~T}>\mathrm{C}\end{array}$ & 6 & 6 & 2.0 & 1.1 & 0.8 \\
\hline${ }^{*} 1 M$ & $-163 \mathrm{C}>\mathrm{A} ; 2159 \mathrm{G}>\mathrm{A}$ & 181 & 343 & 59.9 & 62.6 & 54.8 \\
\hline${ }^{*} 1 \mathrm{~V}$ & -2467 delT; $-163 \mathrm{C}>\mathrm{A}$ & 11 & 15 & 3.6 & 2.7 & $2.8-12.3$ \\
\hline${ }^{*} 1 W$ & $\begin{array}{c}-3113 \mathrm{~A}>\mathrm{G} ;-2467 \mathrm{delT} \\
-739 \mathrm{~T}>\mathrm{G} ;-163 \mathrm{C}>\mathrm{A}\end{array}$ & 5 & 6 & 1.7 & 1.1 & $1.2-2.1$ \\
\hline \multirow[t]{2}{*}{ CYP1A2 genotype } & \multicolumn{3}{|c|}{ Pesuliatric notionts } & \multicolumn{3}{|c|}{ Frequency (\%) } \\
\hline & Tissue donors & \multicolumn{2}{|c|}{ Psychiatric patients } & Tissue donors & \multicolumn{2}{|c|}{ Psychiatric patients } \\
\hline${ }^{*} 1 /{ }^{* 1}$ & 19 & \multicolumn{2}{|c|}{35} & 12.6 & \multicolumn{2}{|c|}{12.8} \\
\hline${ }^{*} 1 /{ }^{*} 1 F$ & 0 & \multicolumn{2}{|c|}{2} & 0 & \multicolumn{2}{|c|}{0.7} \\
\hline${ }^{*} 1 /{ }^{*} 1 L$ & 2 & \multicolumn{2}{|c|}{0} & 1.3 & \multicolumn{2}{|c|}{0} \\
\hline${ }^{*} 1 /{ }^{*} 1 M$ & 54 & \multicolumn{2}{|c|}{96} & 35.8 & \multicolumn{2}{|c|}{35.0} \\
\hline${ }^{*} 1 /{ }^{*} 1 \mathrm{~V}$ & 3 & \multicolumn{2}{|c|}{5} & 2.0 & \multicolumn{2}{|c|}{1.8} \\
\hline${ }^{*} 1 /{ }^{*} 1 W$ & 2 & \multicolumn{2}{|c|}{3} & 1.3 & \multicolumn{2}{|c|}{1.1} \\
\hline${ }^{*} 1 M /{ }^{*} 1 L$ & 4 & \multicolumn{2}{|c|}{4} & 2.6 & \multicolumn{2}{|c|}{1.5} \\
\hline${ }^{*} 1 M /{ }^{*} 1 M$ & 56 & \multicolumn{2}{|c|}{117} & 37.1 & \multicolumn{2}{|c|}{42.7} \\
\hline${ }^{*} 1 M /{ }^{*} 1 V$ & 8 & \multicolumn{2}{|c|}{7} & 5.3 & \multicolumn{2}{|c|}{2.6} \\
\hline${ }^{*} 1 M /{ }^{*} 1 W$ & 3 & \multicolumn{2}{|c|}{2} & 2 & & \\
\hline${ }^{*} 1 V /{ }^{*} 1 L$ & 0 & & & 0 & & \\
\hline${ }^{*} 1 V /{ }^{*} 1 V$ & 0 & & & 0 & & \\
\hline${ }^{*} 1 W /{ }^{*} 1 L$ & 0 & & & 0 & & \\
\hline
\end{tabular}

\subsection{Hepatic CYP1A2 Activities and mRNA Expression}

For characterization of CYP1A2 enzyme activity, phenacetin was used as the CYP1A2selective probe substrate in the microsomal fraction of 131 liver tissue samples. Phenacetin $\mathrm{O}$-dealkylation ranged from extremely low to rather high values, which displayed a skewed distribution and more than two orders of magnitude differences between the lowest and the highest activities [6.76-1107.1 pmol/( $\mathrm{mg} * \mathrm{~min})]$ (Figure 1a). Based on the CYP1A2 activities, the liver tissue donors were classified into poor, intermediate and normal metabolizer phenotype categories, and the cutoff values between the categories were 60.2 and $281.7 \mathrm{pmol} /(\mathrm{mg} * \mathrm{~min})$, according to Temesvári et al. [45]. Of the liver tissues, 68 displayed intermediate CYP1A2 activity, while 31 of the 131 were poor and 32 were characterized as normal metabolizers. Significant association was found between the phenacetin O-dealkylation activity and CYP1A2 mRNA expression in the liver tissues $(\mathrm{N}=73, p<0.0001)$, and substantial differences in hepatic CYP1A2 mRNA expression were observed between poor, intermediate and normal metabolizers (Figure 1b). Furthermore, the differences in the CYP1A2 mRNA expression in leukocytes were also significant between the various CYP1A2 phenotype groups classified by hepatic CYP1A2 activity ( $\mathrm{N}=35, p<0.0001)$ (Figure 1c). 


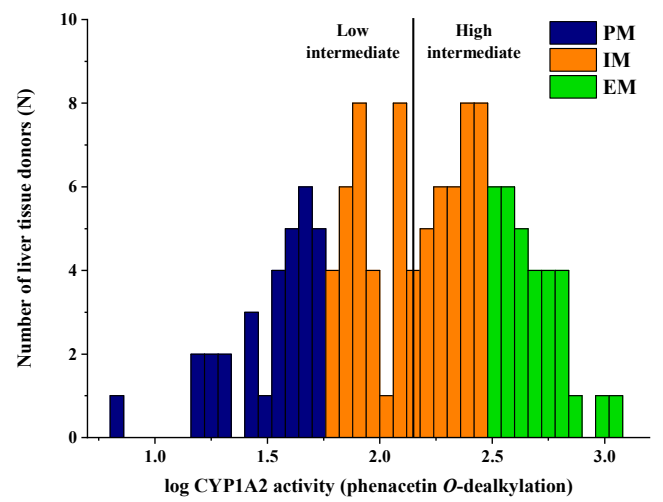

(a)

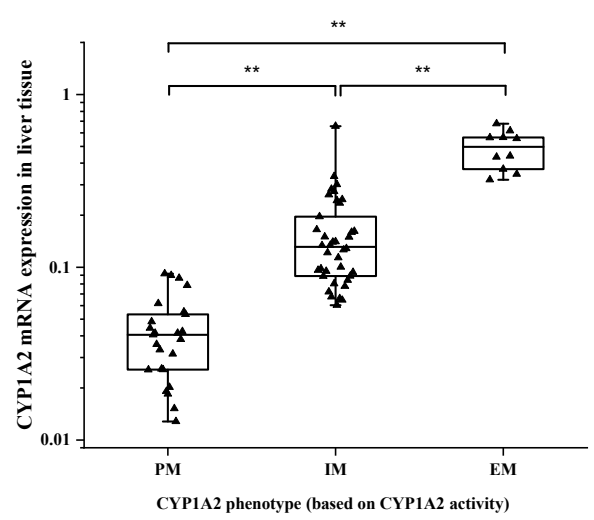

(b)

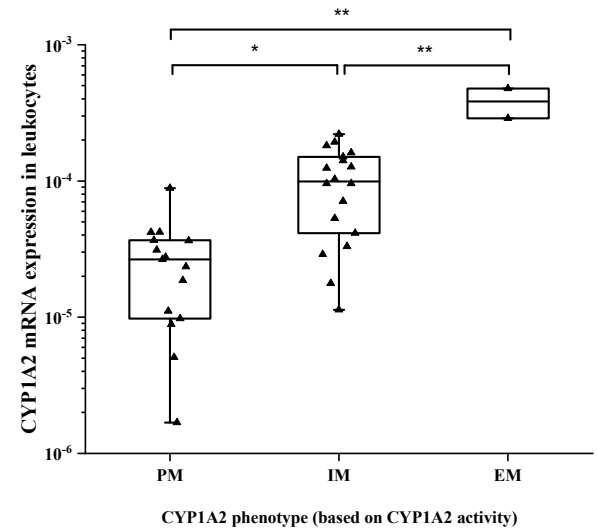

(c)

Figure 1. CYP1A2 activities and expression in liver tissue donors: (a) Frequency distribution of hepatic CYP1A2 activities (phenacetin O-dealkylation); (b) association between CYP1A2 activities and mRNA expression in the liver or (c) mRNA expression in the peripheral leukocytes of human tissue donors. Abbreviations: PM, poor metabolizer; IM, intermediate metabolizer; EM, normal metabolizer. The vertical line between low and high intermediate metabolizers indicates the median activity. In (b) and (c), the boxes display the range; the horizontal lines are for the median, and the whiskers are for the minimum-maximum values. ${ }^{*} p<0.01$; ${ }^{* *} p<0.001$.

\subsection{Impact of $-163 C>A$ (rs762551) on CYP1A2 Activity and $m R N A$ Expression in the Liver}

A higher CYP1A2 inducibility has been reported in subjects carrying -163A in the CYP1A2 regulatory region than in those with $\mathrm{C} / \mathrm{C}$ at -163 position; however, the impact of $-163 \mathrm{C}>\mathrm{A}$ failed to be demonstrated in some studies $[25,26]$. Of 131 liver tissue donors, 115 subjects carried -163A in heterozygous or homozygous form. Approximately half of the tissue donors $(\mathrm{N}=61)$ were homozygous $(-163 \mathrm{~A} / \mathrm{A}), 54$ donors were heterozygous $(-163 \mathrm{C} / \mathrm{A})$ and 16 were $-163 \mathrm{C} / \mathrm{C}$ carriers (Figure $2 \mathrm{a})$. In liver tissue donors, $-163 \mathrm{C}>\mathrm{A}$ polymorphism appeared to have no influence on either the phenacetin $O$-dealkylation activity of CYP1A2 [-163C/C carriers: $150.2 \pm 109.4 \mathrm{pmol} /(\mathrm{mg} * \mathrm{~min}),-163 \mathrm{C} / \mathrm{A}$ carriers: $222.1 \pm 182.4 \mathrm{pmol} /(\mathrm{mg} * \mathrm{~min}),-163 \mathrm{~A} / \mathrm{A}$ carriers: $216.9 \pm 227.5 \mathrm{pmol} /(\mathrm{mg} * \mathrm{~min})$; $\mathrm{N}=131, p=0.425]$ (Figure $2 \mathrm{a}$ ) or the hepatic CYP1A2 mRNA expression (Figure 2b). The proportion of the activity-based poor metabolizers was the same in the three $-163 \mathrm{C}>\mathrm{A}$ groups (22-25\%), whereas normal metabolizers occurred more frequently in -163A carriers than in $-163 \mathrm{C} / \mathrm{C}$ subjects $(6 \%$ in $\mathrm{C} / \mathrm{C}$ carriers vs. $28 \%$ and $26 \%$ in $\mathrm{C} / \mathrm{A}$ and in $\mathrm{A} / \mathrm{A}$ carriers) (Figure 2a); the difference, however, was statistically not significant $(\mathrm{N}=131, p=0.1167)$. (See also the results of multivariate analysis in Section 3.4). 


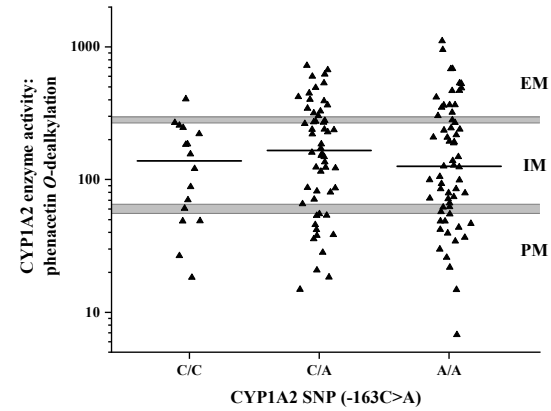

(a)

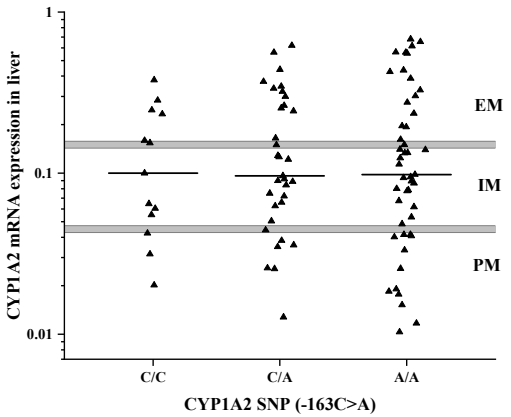

(b)

Figure 2. The association between $-163 C>A$ SNP (rs762551) in the regulatory region of $C Y P 1 A 2$ gene and (a) hepatic CYP1A2 activity or (b) mRNA expression. The horizontal lines display the median values. Abbreviations: PM, poor metabolizer; IM, intermediate metabolizer; EM, normal metabolizer.

3.4. Impact of Genetic and Non-Genetic Factors on Inter-Individual Variation in Hepatic CYP1A2 Activities and Expression

Controversial data have been published about gender and age-related differences in CYP1A2 function [31,46]; therefore, the effect of sex and age on phenacetin $O$-dealkylation activity was investigated in the liver tissue donors. The CYP1A2 activity data were arranged into four groups: males and females as well as under 50 and over 50 years of age (Figure 3a). Only adult subjects ( $>18$ years) were involved in the present study, and further subdivision by age would have been desirable; however, the group-size was unacceptably small. The CYP1A2 activity varied over two orders of magnitude in all four groups, and no significant differences were observed between males and females younger than 50 and older than 50 years old [male < 50 years: $220.6 \pm 222.9 \mathrm{pmol} /(\mathrm{mg} * \mathrm{~min})$, male $>50$ years: $175.3 \pm 145.2 \mathrm{pmol} /(\mathrm{mg} * \mathrm{~min})$, females < 50 years: $228.0 \pm 172.6 \mathrm{pmol} /(\mathrm{mg} * \mathrm{~min})$, females > 50 years: $201.2 \pm 228.9 \mathrm{pmol} /(\mathrm{mg} * \mathrm{~min}), p=0.763]$.

Although no association was found between the $-163 \mathrm{C}>\mathrm{A}$ polymorphism and phenacetin O-dealkylation activity or CYP1A2 mRNA expression, other CYP1A2 SNPs, including $-3860 \mathrm{G}>\mathrm{A},-2467 \mathrm{delT},-739 \mathrm{~T}>\mathrm{G}$ and $2159 \mathrm{G}>\mathrm{A}$, were also considered genetic determinants in CYP1A2 function. PharmVar has indicated several CYP1A2 functional variants, to which decreased activity and expression $\left(C Y P 1 A 2^{*} 1 C, C Y P 1 A 2^{*} 1 K\right)$ or increased inducibility $\left(C Y P 1 A 2^{*} 1 F\right)$ were attributed. In liver tissue donors, neither $C Y P 1 A 2^{*} 1 C, C Y P 1 A 2^{*} 1 K$, nor $C Y P 1 A 2^{*} 1 F$ were identified, because $-3860 \mathrm{G}>\mathrm{A},-163 \mathrm{C}>\mathrm{A}$ or $-739 \mathrm{~T}>\mathrm{G}$ were always in linkage disequilibrium with other CYP1A2 SNPs (Table 2). CYP1A2 haplotype reconstruction identified CYP1A2*1L, CYP1A2*1M, CYP1A2*1V and CYP1A2*1W (Figure $3 \mathrm{~b}, \mathrm{c}$ ), which have not been reported to be associated with altered CYP1A2 activity or expression. CYP1A2*1M, the most frequent allelic variant appeared to have no impact on hepatic phenacetin $O$-dealkylation activity either in heterozygous $\left(C Y P 1 A 2^{*} 1{ }^{*} 1 M\right)$ or in homozygous subjects $\left(C Y P 1 A 2^{*} 1 M{ }^{*} 1 M\right)$ com-

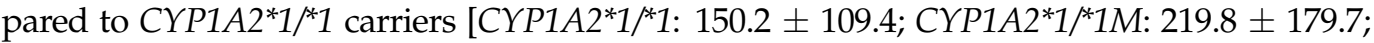
CYP1A2*1M/ $\left.{ }^{*} 1 M: 194.3 \pm 194.4 \mathrm{pmol} /(\mathrm{mg} * \mathrm{~min}), \mathrm{N}=118, p=0.393\right]$ (Figure 3b). Furthermore, no association between CYP1A2 mRNA expression and CYP1A2*1M was demonstrated (CYP1A2*1/*1: $0.141 \pm 0.114 ;$ CYP1A2*1/*1M: $0.163 \pm 0.138 ; C Y P 1 A 2 * 1 M /{ }^{*} 1 M: 0.145 \pm 0.149$, $\mathrm{N}=73, p=0.851$ ) (Figure $3 \mathrm{c}$ ). In other CYP1A2 genotype groups, the number of data was insufficient for statistical analysis. 


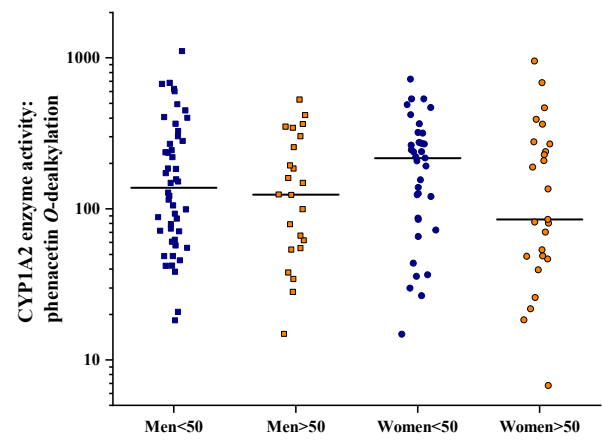

(a)

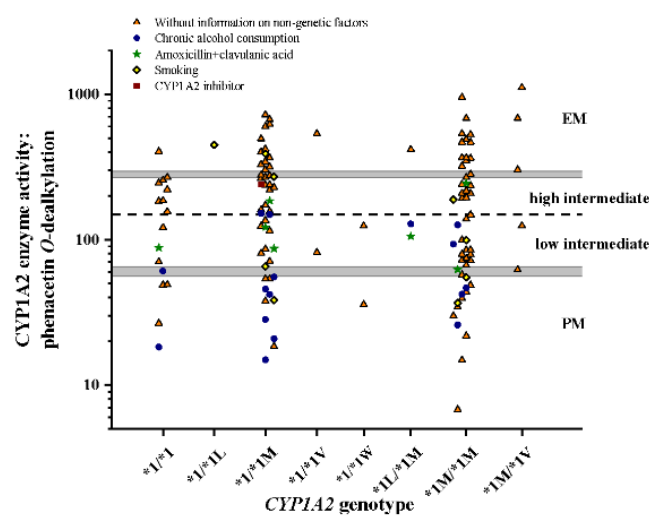

CYP1A2 activity reducing non-genetic factors

\begin{tabular}{c|cc} 
& Not reported & Reported \\
\hline PM+Low IM & 45 & 20 \\
High IM+EM & 62 & 4 \\
& \multicolumn{2}{|c|}{$p=0.0002$}
\end{tabular}

(b)

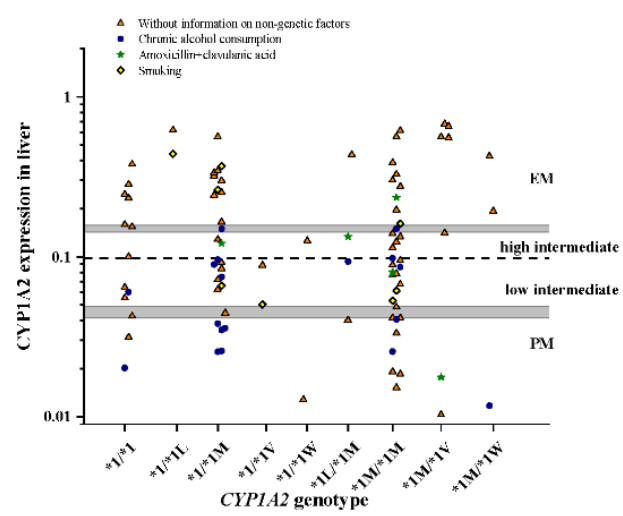

CYP1A2 expression reducing non-genetic factors

\begin{tabular}{c|cc} 
& Not reported & Reported \\
\hline PM+Low IM & 28 & 16 \\
High IM+EM & 42 & 5 \\
& \multicolumn{2}{|c}{$p=0.0055$}
\end{tabular}

(c)

Figure 3. The effect of genetic and non-genetic factors on hepatic CYP1A2 activity (phenacetin O-dealkylation) and CYP1A2 expression in liver tissue donors: (a) The influence of gender and age of the subjects on CYP1A2 activity ( $<50$ years old in blue, $>50$ years old in orange); (b) the impact of CYP1A2 genetic variations and non-genetic factors (CYP1A2 inhibitor therapy, smoking, amoxicillin+clavulanic acid treatment, chronic alcohol consumption) on CYP1A2 activity and (c) on mRNA expression are presented. The median CYP1A2 activity (dotted line) is for the cutoff value between high and low intermediate metabolizers. Tables provide the number of subjects in various metabolizer groups with the information of relevant non-genetic factors. Abbreviations: PM, poor metabolizer; IM, intermediate metabolizer; EM, normal metabolizer.

In addition to the CYP1A2 genetic variations, the impact of non-genetic factors on CYP1A2 activity and mRNA expression was also investigated (Figure 3b,c). The CYP1A2inducing factor (smoking) and the CYP1A2 inhibitor ciprofloxacin, as well as non-specific non-genetic factors (chronic alcohol consumption and amoxicillin+clavulanic acid therapy) that can modify (increase or decrease) CYP1A2 activity and/or expression, were considered in the evaluation of CYP1A2 function $[16,47]$. Due to the incomplete smoking data in the clinical histories of the liver tissue donors, the CYP1A2-inducing effect of smoking was not evaluated in these subjects. However, smoking status was accurately reported for the patients with psychiatric disorders; therefore, the impact of this non-genetic factor was reliably assessed in this patient population. Although the 16 liver tissue donors with CYP $1 A 2^{*} 1{ }^{*} 1$ genotype were expected to be intermediate metabolizers, four displayed 
poor metabolism and one displayed normal metabolism. Among the poor metabolizers carrying $C Y P 1 A 2^{*} 1{ }^{*} 1$, two subjects reported chronic alcohol consumption, whereas one tissue donor, classified as low intermediate metabolizer, received amoxicillin+clavulanic acid therapy that likely explained the low phenacetin $O$-dealkylation. The CYP1A2 activity of the 49 organ donors carrying $C Y P 1 A 2 * 1 /{ }^{*} 1 M$ genotype ranged from poor to normal metabolism [14.85-724 pmol/(mg * min)]. Chronic alcohol consumption $(\mathrm{N}=7)$ and amoxicillin+clavulanic acid therapy $(\mathrm{N}=2)$ as non-specific non-genetic factors explained the poor and low intermediate CYP1A2 activity in nine subjects, whereas the CYP1A2 inhibitor ciprofloxacin did not shift CYP1A2 activity into the poor metabolizer category. In the 53 tissue donors with $C Y P 1 A 2^{*} 1 M /{ }^{*} 1 M$ genotype, phenacetin $O$-dealkylation activity ranged from $6.76 \mathrm{pmol} /(\mathrm{mg} * \mathrm{~min})$, the lowest, to $950.2 \mathrm{pmol} /(\mathrm{mg} * \mathrm{~min})$, the highest. Similar to subjects with the CYP1A2*1/*1M genotype, chronic alcohol consumption $(\mathrm{N}=5)$ and amoxicillin+clavulanic acid therapy $(\mathrm{N}=1)$ in the clinical histories of the CYP1A2* $1 M /{ }^{*} 1 M$ carriers were associated with poor and low intermediate CYP1A2 activity. In the other CYP1A2 genotype groups, either no information about non-genetic factors was available, or the non-specific non-genetic factors were found in the clinical histories (in CYP1A2*1L/ ${ }^{*} 1 M$ : one subject with chronic alcohol consumption and one with amoxicillin+clavulanic acid therapy), which explained the low intermediate activity. Taken together, non-specific non-genetic factors were assumed to be responsible for the poor and low intermediate CYP1A2 activity in 20 of 65 tissue donors (chronic alcohol consumption: 15; amoxicillin+clavulanic acid therapy: five), whereas in those subjects with high intermediate and normal metabolism $(\mathrm{N}=66)$, non-genetic factors were identified in the clinical histories of four tissue donors (chronic alcohol consumption: one; amoxicillin+clavulanic acid therapy: two; ciprofloxacin: one). In other words, the CYP1A2 activity-reducing nongenetic factors were reported more frequently in the poor and low intermediate metabolizer subjects than in the high intermediate and normal metabolizers (20/65 vs. 4/66; OR: 6.889, 95\%CI: 2.202-21.548, $p=0.0002$ ) (Figure 3b).

The impact of non-specific non-genetic factors (chronic alcohol consumption, amoxicillin+clavulanic acid therapy) on CYP1A2 mRNA expression in the liver was established in 93 liver tissue donor subjects (Figure 3c). Ciprofloxacin has been demonstrated to exert an inhibitory effect on the CYP1A2 enzyme protein [44,48]; however, it was not considered a non-genetic factor that can modify CYP1A2 expression. Hepatic CYP1A2 mRNA expression was influenced by non-specific non-genetic factors similar to phenacetin $O$-dealkylation activity. Chronic alcohol consumption $(\mathrm{N}=16)$ and amoxicillin+clavulanic acid therapy $(\mathrm{N}=2)$ were likely to be responsible for the poor and low intermediate CYP1A2 expression in 18 of 46 tissue donors, whereas these non-genetic factors were found in the clinical histories of five high intermediate and normal metabolizers. Non-specific non-genetic factors were more frequently reported in those subjects with reduced CYP1A2 expression than in the high intermediate and normal expressers (18/46 vs. 5/47; OR: 5.4, 95\%CI: 1.797-16.23, $p=0.0017$ ) (Figure 3c).

A multiple linear regression analysis was also performed to estimate the influence of genetic (CYP1A2 SNPs or haplotypes) and non-genetic covariates (sex, age, medication with amoxicillin+clavulanic acid and chronic alcohol consumption) on CYP1A2 activity and on CYP1A2 mRNA expression (Table 3). Significant associations were observed between phenacetin $O$-dealkylation activity and nucleotide deletion $-2467 \mathrm{delT}(p=0.011)$, age $(p=0.027)$ or chronic alcohol consumption $(p<0.001)$. When the CYP1A2 haplotypes were considered, the impact of the $-3860 \mathrm{G} /-2467 \mathrm{delT} /-739 \mathrm{~T} /-163 \mathrm{~A} / 2159 \mathrm{G}$ haplotype, designated as CYP1A2*1V, was significant $(p=0.004)$, and age $(p=0.024)$ and CYP1A2 activity-reducing non-genetic factors (chronic alcohol consumption and amoxicillin+clavulanic acid therapy) appeared to be associated with phenacetin $O$-dealkylation activity $(p<0.001)$. Furthermore, hepatic CYP1A2 mRNA expression was significantly associated with the -2467 delT $(p=0.011)$, amoxicillin+clavulanic acid therapy $(p=0.050)$ or chronic alcohol consumption $(p=0.004)$, but not with the age $(p=0.128)$. Involving CYP1A2 haplotypes in the multiple regression model, the association between CYP1A2 mRNA expression and the -3860A/-2467delT/-739T/-163A/2159G and $-3860 \mathrm{G} /-2467 \mathrm{delT} /-739 \mathrm{~T} /-163 \mathrm{~A} / 2159 \mathrm{G}$ haplotypes, present in CYP1A2*1L and 
CYP1A2 ${ }^{*} 1 V$ alleles, became significant ( $p=0.019$ and $p=0.009$, respectively). The CYP1A2 expression that reduces non-genetic factors displayed significant association with hepatic CYP1A2 expression $(p=0.002)$. However, sex appeared to have no influence on either the CYP1A2 activity or mRNA expression.

\subsection{Impact of Genetic and Non-Genetic Factors on CYP1A2 mRNA Expression in Psychiatric Patients}

The CYP1A2 genotype of the patients with psychiatric disorders was determined from CYP1A2 SNP data (including $-3860 \mathrm{G}>\mathrm{A},-2467 \mathrm{delT},-739 \mathrm{~T}>\mathrm{G},-163 \mathrm{C}>\mathrm{A}$ and $2159 \mathrm{G}>\mathrm{A}$ ) by haplotype analysis, whereas the hepatic CYP1A2 function was estimated from CYP1A2 mRNA expression in patients' leukocytes. Four orders of magnitude difference in the CYP1A2 expression were observed between the lowest and the highest mRNA levels (Figure 4a). Approximately two thirds of the patients were classified as CYP1A2 poor metabolizers, $31 \%$ as intermediate and only $2.6 \%$ as normal metabolizers. In psychiatric patients, no association was found between the CYP1A2 genotypes and CYP1A2 mRNA expression in leukocytes $(\mathrm{N}=274, p=0.1165)$ (Figure $4 \mathrm{a})$.

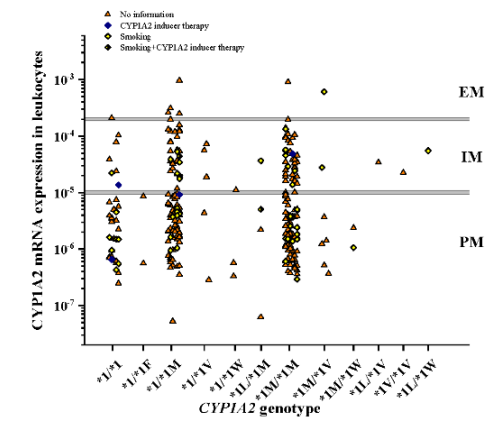

CYP1A2 expression increasing non-genetic factors

\begin{tabular}{c|cc} 
& Not reported & Reported \\
\hline PM & 149 & 33 \\
IM+EM & 70 & 22 \\
& \multicolumn{2}{|c}{$p=0.2674$}
\end{tabular}

(a)



(c)



(b)

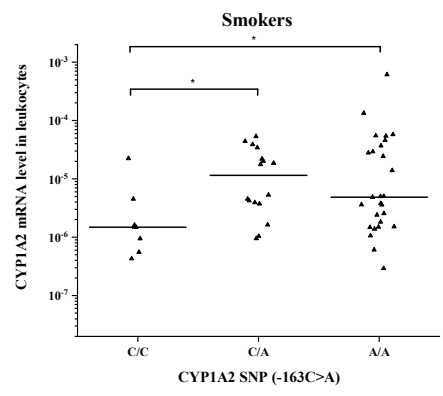

(d)

Figure 4. The effect of genetic and non-genetic factors on CYP1A2 expression in the leukocytes of patients with psychiatric disorders: The impact of $C Y P 1 A 2$ genetic variations and non-genetic factors (CYP1A2-inducer therapy, smoking) on CYP1A2 expression (a) and the influence of smoking on mRNA expression (b-d) are presented. The horizontal lines display the median values. The table provides the number of subjects in various metabolizer groups with the information of relevant non-genetic factors. Abbreviations: PM, poor metabolizer; IM, intermediate metabolizer; EM, normal metabolizer; $* p<0.05$. 
Table 3. Multivariate analysis of CYP1A2 activity (phenacetin O-dealkylation) and mRNA expression, considering genetic (CYP1A2 SNPs or haplotypes) and non-genetic factors in liver tissue donors.

\begin{tabular}{|c|c|c|c|c|c|c|c|}
\hline \multirow{2}{*}{ Variable } & & \multicolumn{3}{|c|}{ CYP1A2 Activity } & \multicolumn{3}{|c|}{ CYP1A2 mRNA Expression } \\
\hline & & Coefficient B (SE) & Coefficient $B$ & $p$ Value & Coefficient B (SE) & Coefficient $\beta$ & $p$ Value \\
\hline \multirow{8}{*}{ SNPs, non-genetic } & Constant & $124.92(54.99)$ & & 0.025 & $0.125(0.052)$ & & 0.017 \\
\hline & $-3860 \mathrm{G}>\mathrm{A}(\mathrm{rs} 2069514)$ & $-87.27(119.26)$ & -0.077 & 0.466 & $0.014(0.086)$ & 0.021 & 0.867 \\
\hline & -2467delT (rs35694136) & $212.01(81.90)$ & 0.312 & 0.011 & $0.164(0.063)$ & 0.385 & 0.011 \\
\hline & $-739 \mathrm{~T}>\mathrm{G}(\mathrm{rs} 20695)$ & $-288.73(218.63)$ & -0.128 & 0.189 & $-0.130(0.100)$ & -0.154 & 0.198 \\
\hline & $2159 \mathrm{G}>\mathrm{A}(\mathrm{rs} 2472304)$ & $70.81(127.58)$ & 0.130 & 0.580 & $0.084(0.088)$ & 0.194 & 0.341 \\
\hline & Sex & $-8.02(34.82)$ & -0.020 & 0.818 & $-0.023(0.040)$ & -0.066 & 0.569 \\
\hline & Age & $78.69(35.06)$ & 0.191 & 0.027 & $0.058(0.038)$ & 0.166 & 0.128 \\
\hline & Chronic alcohol consumption & $-170.67(50.01)$ & -0.292 & $<0.001$ & $-0.146(0.049)$ & -0.338 & 0.004 \\
\hline \multirow{8}{*}{$\begin{array}{l}\text { Haplotypes, } \\
\text { non-genetic }\end{array}$} & Constant & $124.12(51.83)$ & & 0.018 & $0.119(0.046)$ & & 0.011 \\
\hline & $-3860 \mathrm{~A} /-2467 \mathrm{delT} /-739 \mathrm{~T} /-\mathbf{1 6 3 A} / 2159 \mathrm{G}$ & $127.91(95.67)$ & 0.112 & 0.184 & $0.166(0.069)$ & 0.238 & 0.019 \\
\hline & $-3860 \mathrm{G} /-2467 \mathrm{~T} /-739 \mathrm{~T} /-\mathbf{1 6 3 A} / \mathbf{2 1 5 9 A}$ & $68.27(46.56)$ & 0.125 & 0.145 & $0.057(0.044)$ & 0.132 & 0.199 \\
\hline & $-3860 \mathrm{G} /-2467 \mathrm{delT} /-739 \mathrm{~T} /-163 \mathrm{~A} / 2159 \mathrm{G}$ & $211.41(72.86)$ & 0.243 & 0.004 & $0.154(0.058)$ & 0.267 & 0.009 \\
\hline & $-3860 \mathrm{G} /-2467 \mathrm{delT} /-739 \mathrm{G} /-163 \mathrm{~A} / 2159 \mathrm{G}$ & $-79.18(190.15)$ & -0.035 & 0.678 & $0.027(0.082)$ & 0.032 & 0.743 \\
\hline & Sex & $-7.59(34.35)$ & -0.019 & 0.825 & $-0.021(0.039)$ & -0.060 & 0.592 \\
\hline & Age & 79.19 (34.76) & 0.193 & 0.024 & $0.057(0.037)$ & 0.163 & 0.127 \\
\hline & Activity reducing factors & $-160.33(43.82)$ & -0.316 & $<0.001$ & $-0.149(0.045)$ & -0.375 & 0.002 \\
\hline
\end{tabular}

In haplotypes, the polymorphic variants were indicated in bold. The $p$ values $<0.05$ were considered to be statistically significant and are indicated in bold. 
The polycyclic aromatic hydrocarbons in tobacco smoke have been demonstrated to increase CYP1A2 activity by increasing the CYP1A2 expression via the AhR-mediated signalization pathway [49]. In the liver tissue donors, the contribution of smoking as a CYP1A2-inducing factor to CYP1A2 expression was not evaluated because of incomplete information about their smoking status. However, smoking habits and CYP1A2-inducer therapy (with carbamazepine) were well documented in the group of patients with psychiatric disorders; therefore, the impact of these non-genetic phenoconverting factors on the CYP1A2 expression was reliably investigated (Figure 4). Smoking and CYP1A2inducer carbamazepine therapy were reported in most of the CYP1A2 genotype groups and in both poor and intermediate/normal metabolizers. However, no significant differences in the frequency of the CYP1A2-inducing factors in the clinical histories were observed between the poor and intermediate/normal metabolizers (33/182 vs. 22/92, $p=0.2674)$. Furthermore, smoking seemed to have no influence on CYP1A2 expression when CYP1A2 genetic factors were not considered (non-smokers: $3.23 \times 10^{-5} \pm 9.99 \times 10^{-5}$; smokers: $\left.2.82 \times 10^{-5} \pm 8.65 \times 10^{-5}, p=0.7858\right)$ (Figure $4 \mathrm{~b}$ ).

According to several previous studies, the CYP1A2-inducing effect of tobacco smoking is more prominent in subjects with $-163 \mathrm{C}>\mathrm{A}$ SNP in the CYP1A2-regulatory region than in those with $-163 \mathrm{C} / \mathrm{C}$ [20,50]; therefore, we evaluated the effect of -163A on CYP1A2 inducibility, both in smokers and in non-smoker patients. Those patients who were on carbamazepine therapy were excluded from the evaluation $(\mathrm{N}=6)$. In the non-smokers, no significant differences in the CYP1A2 mRNA level were observed between various CYP1A2 -163C>A carriers $\left(-163 \mathrm{C} / \mathrm{C}: 2.02 \times 10^{-5} \pm 4.67 \times 10^{-5} ;-163 \mathrm{C} / \mathrm{A}: 4.31 \times 10^{-5} \pm 1.16 \times 10^{-4} ;-163 \mathrm{~A} / \mathrm{A}\right.$ : $2.59 \times 10^{-5} \pm 9.36 \times 10^{-5}, \mathrm{~N}=268 ; p=0.4028$ ) (Figure $4 \mathrm{c}$ ). Of the 52 smoker subjects, the wild-type $-163 \mathrm{C} / \mathrm{C}$ carriers had significantly lower CYP1A2 mRNA expression in leukocytes compared to patients with $-163 \mathrm{C} / \mathrm{A}$ and $-163 \mathrm{~A} / \mathrm{A}\left(-163 \mathrm{C} / \mathrm{C}: 4.17 \times 10^{-6} \pm 7.45 \times 10^{-6}\right.$; $-163 \mathrm{C} / \mathrm{A}: 1.71 \times 10^{-5} \pm 1.71 \times 10^{-5} ;-163 \mathrm{~A} / \mathrm{A}: 4.20 \times 10^{-5} \pm 1.16 \times 10^{-4}, \mathrm{~N}=52$, $p=0.0369$ ) (Figure $4 \mathrm{~d}$ ).

\section{Discussion}

The present work investigated the association between CYP1A2 genetic polymorphisms and CYP1A2-selective phenacetin O-dealkylation activity or CYP1A2 mRNA expression in human liver tissues and in psychiatric patients belonging to Caucasian populations. A high inter-individual variability in the CYP1A2 activity and expression was observed in the liver tissue donors, which was consistent with the results obtained from human liver samples in a recent study by Liu et al. [31] and with the CYP1A2 phenotype prediction in patients by Lorenzini et al. [51]. The frequencies of the liver tissue donors with poor, intermediate and normal CYP1A2 activities were more or less similar to the frequency distribution of poor, normal and ultra-rapid metabolizer phenotypes in patients reported by Lorenzini et al. [51]. In a previous study [52], a strong correlation was reported between hepatic CYP1A2 activity and mRNA expression, which was confirmed by our findings in the liver tissue donors. Furthermore, a significant association between the hepatic CYP1A2 enzyme activity and mRNA expression in leukocytes was observed, similar to the previous findings by Temesvári et al. [45]; thus, CYP1A2 mRNA expression in leukocytes appeared to be an appropriate, less-invasive marker for the estimation of hepatic CYP1A2 activity in patients.

The substantial variability in hepatic CYP1A2 function was attributed to both genetic polymorphisms and non-genetic factors [10,27,51]. Several CYP1A2 allelic variants have been associated with altered CYP1A2 activity and/or mRNA expression. CYP1A2*1F has been reported to be one of the most common allelic variants, with $32-57 \%$ allele frequencies in Caucasian populations [20,44,53]; however, due to the close genetic linkage between -163 C >A SNP and other SNPs (e.g., -3860G >A, -2467delT, -739T>G or 2159G>A), generating haplotypes other than $C Y P 1 A 2^{*} 1 F$, the frequency data should be applied to $-163 \mathrm{~A}$ rather than to $C Y P 1 A 2^{*} 1 F$ [54]. When involving the most common SNPs in the haplotype reconstruction, we found $C Y P 1 A 2 * 1 F$ to be one of the rarest CYP1A2 haplotypes, with a frequency of $0.4 \%$ in the subjects of the present study. Although the extremely low 
frequency of $C Y P 1 A 2 * 1 F$ did not allow for an association analysis with CYP1A2 activity and expression, the most frequent $-163 \mathrm{C}>\mathrm{A}$ SNP $(67 \%)$ was found to have no influence on the hepatic phenacetin O-dealkylation activity or on the CYP1A2 mRNA expression. The $-163 \mathrm{C}>\mathrm{A}$ SNP has been suggested to be associated with increased inducibility; however, the contribution of $-163 \mathrm{C}>\mathrm{A}$ to increased CYP1A2 activity is inconsistent in the literature [15-21]. Increased caffeine metabolism (high paraxanthine/caffeine ratio) was demonstrated only in smokers carrying -163A/A, compared to those carrying $-163 \mathrm{C} / \mathrm{C}$ or $-163 \mathrm{C} / \mathrm{A}[17,20]$. Furthermore, significantly lower olanzapine serum concentrations were observed in smokers with -163A/A, compared to those observed in the heterozygous or homozygous wild-type subjects [19]. Our findings confirmed the results of these previous studies; particularly the finding that elevated CYP1A2 mRNA expression was found in the smoker psychiatric patients carrying two, or even one, $-163 \mathrm{~A}(-163 \mathrm{~A} / \mathrm{A}$ or $163 \mathrm{C} / \mathrm{A}$ ), compared to those with the wild-type $-163 \mathrm{C} / \mathrm{C}$. However, no association between CYP1A2 expression and $-163 \mathrm{C}>\mathrm{A}$ polymorphism was observed in non-smoker patients. Dobrinas et al. have reported high paraxanthine/caffeine ratios in subjects carrying -163A, regardless of smoking [16]; however, in the liver tissue donors with incomplete smoking information in the present study, no association was found between $-163 \mathrm{C}>\mathrm{A}$ polymorphism and either phenacetin O-dealkylation activity or CYP1A2 mRNA expression. Decreased CYP1A2 activity has been attributed to CYP1A2*1C (-3860G>A) [16,20,24], whereas controversial results of CYP1A2 inducibility have been reported in CYP1A2* $1 D$ $(-2467 \mathrm{delT})$-carrier smokers $[16,18,20,55,56]$. In the liver tissue donors and patients with psychiatric disorders involved in the present study, the $-3860 \mathrm{G}>\mathrm{A}$ and $-2467 \mathrm{delT}$ SNPs were identified with frequencies similar to other European populations [20,55]; however, these SNPs were in linkage disequilibrium with $-163 \mathrm{C}>\mathrm{A}$ in $C Y P 1 A 2 * 1 L, C Y P 1 A 2 * 1 V$ and CYP1A2* $1 W$. The $-3860 \mathrm{G}>\mathrm{A}$ SNP was found to have no impact on CYP1A2 function, whereas the $-2467 \mathrm{delT}$ SNP and CYP1A2* $1 \mathrm{~V}$ allele appeared to contribute to increased CYP1A2 activity and mRNA expression in liver tissues. Although the CYP1A2*1L-carrier subjects also displayed increased CYP1A2 mRNA expression, phenacetin $O$-dealkylation activity was not influenced by the $C Y P 1 A 2^{*} 1 L$ allele. The $C Y P 1 A 2 * 1 M$ allelic variant most common in Caucasian populations [25] occurred in approximately $60 \%$ of tissue donors and psychiatric patients and appeared to have no significant effect on CYP1A2 activity and expression.

For several CYPs and other drug-metabolizing enzymes, pharmacogenetic testing has been considered a useful tool for identification of high-risk patients with loss-of-function or gain-of-function alleles, and plenty of pharmacogenetic guidelines recommend dose adjustment of a drug to the patients' genetic information [57-60]. For CYP1A2, no pharmacogenetic guideline has been published yet, most likely because several common CYP1A2 SNPs are in the regulatory elements of the promoter region or in intron 1, and the complex regulatory mechanisms require the action of non-genetic phenoconverting factors. In the present study, we have demonstrated a minor association between SNPs in the regulatory regions of the CYP1A2 gene or CYP1A2 haplotypes and CYP1A2 activity or expression either in liver tissue donors or in psychiatric patients. Our results are in concordance with the conclusion of a recent clinical study [61] which found that CYP1A2 genotyping has no, or minor clinical relevance in treatment with CYP1A2 substrate drugs. Several non-genetic intrinsic and environmental factors, such as age, sex, hormones, diseases, alcohol consumption and medication have been reported to modify CYP1A2 activity and expression $[10,27,62]$. Men have been demonstrated to have significantly higher microsomal CYP1A2 activity than women [29], whereas a significant decline in CYP1A2 activity was observed with age [46]. Although our results confirmed the decreased CYP1A2 activity in the subjects older than 50 years of age, no significant association between sexes and hepatic CYP1A2 activity or expression was found, similar to a recent study by Liu et al. [31]. Several clinical studies demonstrated that oral contraceptives contributed to decreased CYP1A2 activity by influencing hormonal status [36,62]. In the clinical histories of the liver tissue donors, treatment with oral contraceptives was not reported; however, chronic 
alcohol consumption or amoxicillin+clavulanic acid therapy as non-specific non-genetic factors that significantly decreased the CYP1A2 activity and expression were indicated. A large body of evidence has been provided to demonstrate that the pathomechanism of liver disease induced by chronic alcohol consumption (inflammation, oxidative stress) was related to impaired drug metabolism [63-65]. The antibiotic amoxicillin, in combination with clavulanic acid, has been reported to lead rarely to drug-induced liver injury or severe acute liver failure [66,67]. Although no information is available about the CYP1A2-selective inhibitory effect or downregulation of the CYP1A2 expression by chronic alcohol consumption or amoxicillin+clavulanic acid therapy, hepatotoxicity-related inflammation might have influenced the CYP1A2 function and/or expression. We have previously demonstrated that these non-specific non-genetic factors were mainly responsible for poor and low intermediate metabolism by CYP2C9 and CYP2C19 [68,69]. In addition to non-specific chronic alcohol consumption and amoxicillin+clavulanic acid therapy, CYP1A2-specific inducer and inhibitor therapy has clearly demonstrated contribution to the inter-individual variability in CYP1A2 activity and to be the major causes of phenoconversion of genetically determined CYP1A2 activities [35]. Co-administration of ciprofloxacin, the potent CYP1A2 inhibitor, has been found to significantly elevate the serum concentrations and exposure to CYP1A2 substrates [47]. For one liver tissue donor, ciprofloxacin therapy was indicated in the clinical history; however, inhibition of the hepatic phenacetin $O$-dealkylation was not observed. The inducibility of the CYP1A2 gene via the AhR-mediated signaling pathway is well documented, and exposure to CYP1A2-specific inducing factors (carbamazepine, components of cigarette smoke) is logically expected to increase transcriptional expression of CYP1A2. Clinical studies have shown that smoking increased the clearance and reduced the plasma concentrations of CYP1A2 substrate drugs, such as clozapine or olanzapine [70,71] Most of the studies reported 1.1-2-fold differences in CYP1A2 activity between smokers and non-smokers [44]. In contrast, no significant differences in CYP1A2 expression were observed between smoker and non-smoker patients with psychiatric disorders, when we did not consider genetic factors. However, the CYP1A2 inducing effect of smoking was demonstrated in the $-163 \mathrm{~A}$ carrier patients. Furthermore, treatment with the CYP1A2 inducer carbamazepine has been reported to significantly reduce the serum concentration of the CYP1A2 substrate olanzapine [19,72]. In the patients with psychiatric disorders, only six were on carbamazepine therapy, three displayed intermediate CYP1A2 expression and three were CYP1A2 poor metabolizers. Due to the low number of patients on carbamazepine therapy and the wide range of CYP1A2 expression, we could not confirm the CYP1A2-inducing effect of carbamazepine.

The present study has some limitations that should be discussed. First, we did not evaluate the effect of CYP1A2 SNPs other than -3860G >A (rs2069514), -2467delT (rs35694136), $-739 \mathrm{~T}>\mathrm{G}$ (rs2069526), $-163 \mathrm{C}>\mathrm{A}$ (rs762551) or 2159G $>\mathrm{A}$ (rs2472304), which are present in the CYP1A2*1C, CYP1A2*1D, CYP1A2*1E, CYP1A2*1F, CYP1A2*1L, CYP1A2*1M, $C Y P 1 A 2 * 1 V$ or $C Y P 1 A 2 * 1 W$ alleles. However, other $C Y P 1 A 2$ alleles associated with altered CYP1A2 activity or expression (e.g., CYP1A2*3, CYP1A2*4, CYP1A2*6, CYP1A2*7, $C Y P 1 A 2^{*} 8, C Y P 1 A 2^{*} 11$ and $\left.C Y P 1 A 2^{*} 15\right)$ have not been reported or have been detected at a low prevalence in Caucasian populations $[43,73]$. Second, $C Y P 1 A 2^{*} 1 F$ was not identified in the liver tissue donors and was detected at extremely low frequency $(0.4 \%)$ in the patients with psychiatric disorders; therefore, the effect of CYP1A2* $1 F$ on CYP1A2 activity or expression was not assessed. Third, no information about oral contraceptive therapy and incomplete information about smoking status was available in the clinical histories of the liver tissue donors. Although the impact of smoking on CYP1A2 expression was reliably evaluated in the patients with psychiatric disorders, oral contraceptives were not applied in these patients; therefore, no conclusion on the CYP1A2 activity-reducing effect of these drugs could be drawn. 


\section{Conclusions}

The CYP1A2 alleles, including CYP1A2*1C, CYP1A2*1D, CYP1A2*1F, CYP1A2*1L, $C Y P 1 A 2 * 1 M, C Y P 1 A 2^{*} 1 \mathrm{~V}$ and $C Y P 1 A 2^{*} 1 \mathrm{~W}$, were reconstructed from $-3860 \mathrm{G}>\mathrm{A},-2467 \mathrm{delT}$, $-739 \mathrm{~T}>\mathrm{G},-163 \mathrm{C}>\mathrm{A}$ or $2159 \mathrm{G}>\mathrm{A}$ SNP data in liver tissue donors and in patients with psychiatric disorders. CYP1A2* $1 F$, generally identified by the presence of $-163 C>A$ polymorphism, has been considered one of the most common CYP1A2 alleles (32-57\%); however, due to linkage disequilibrium of $-163 \mathrm{C}>\mathrm{A}$ with other CYP1A2 SNPs, the CYP1A2*1F allele was identified at an extremely low frequency $(0-0.4 \%)$ in the subjects of the present study. A high inter-individual variability in the phenacetin $O$-dealkylation activity and CYP1A2 mRNA expression was detected in the liver tissue donors; however, the CYP1A2 genetic polymorphisms appeared to have a minor impact on the hepatic CYP1A2 activity and expression. Non-genetic factors, such as smoking, chronic alcohol consumption and amoxicillin+clavulanic acid therapy, were found to influence CYP1A2 expression and activity. Smoking, the CYP1A2-inducing factor, contributed to increased CYP1A2 expression in -163A carrier patients, whereas the non-specific non-genetic factors, chronic alcohol consumption and amoxicillin+clavulanic acid treatment, were associated with decreased CYP1A2 function and expression. Although CYP polymorphism analysis generally provides significant information in the prediction of CYP-mediated metabolism, for CYP1A2, non-genetic factors, rather than genetic polymorphisms, appeared to contribute to CYP1A2 function. Furthermore, a strong association was demonstrated between the hepatic CYP1A2 activity and CYP1A2 mRNA expression in the liver or in the peripheral leukocytes. Therefore, an analysis of CYP1A2 mRNA expression in leukocytes, rather than CYP1A2 genetic variants, may provide an appropriate tool for accurate prediction of hepatic CYP1A2 function and for the estimation of patients' CYP1A2-metabolizing capacity toward drugs, such as clozapine, olanzapine, duloxetine, theophylline or tacrine.

Supplementary Materials: The following supporting information can be downloaded at: https: //www.mdpi.com/article/10.3390/pharmaceutics14030532/s1. Table S1: Sequences of primers and fluorophore-labelled probe oligonucleotides for real-time PCR assaying CYP1A2 SNPs. Table S2: The flowchart of data analysis obtained from liver tissues.

Author Contributions: Study conception and design: K.M. (Katalin Monostory) and F.F.; CYP genotyping, measurement of enzyme activity and expression: F.F., K.M. (Katalin Mangó), A.M. and K.T.; data analysis and interpretation: F.F. and K.M. (Katalin Monostory); manuscript drafting: F.F. and K.M. (Katalin Monostory). All authors have read and agreed to the published version of the manuscript.

Funding: This study was supported by the National Research, Development and Innovation Fund of Hungary (2020-1.1.2-PIACI-KFI-2020-00021) and by the grant: VEKOP-2.3.3-15-2017-00014.

Institutional Review Board Statement: The present study was approved by the Hungarian Committee of Science and Research Ethics, Medical Research Council [4799-0/2011EKU (125/PI/2011), 14737-0/2010-1018EKU (638/PI/010)]. The study was performed in accordance with the relevant guidelines and regulations (Act CLIV of 1997 on Health, decree 23/2002 of the Minister of Health of Hungary and the Declaration of Helsinki).

Informed Consent Statement: Written informed consent was obtained from the participants involved in the study.

Data Availability Statement: Data are contained within the article.

Acknowledgments: The authors are indebted to János Fekete for his valuable advice on statistical analysis.

Conflicts of Interest: The authors declare no conflict of interest. 


\section{References}

1. Shimada, T.; Yamazaki, H.; Mimura, M.; Inui, Y.; Guengerich, F.P. Interindividual variations in human liver cytochrome P-450 enzymes involved in the oxidation of drugs, carcinogens and toxic chemicals: Studies with liver microsomes of 30 Japanese and 30 Caucasians. J. Pharmacol. Exp. Ther. 1994, 270, 414-423. [PubMed]

2. Mercurio, M.G.; Shiff, S.J.; Galbraith, R.A.; Sassa, S. Expression of cytochrome P450 mRNAs in the colon and the rectum in normal human subjects. Biochem. Biophys. Res. Commun. 1995, 210, 350-355. [CrossRef] [PubMed]

3. Furukawa, M.; Nishimura, M.; Ogino, D.; Chiba, R.; Ikai, I.; Ueda, N.; Naito, S.; Kuribayashi, S.; Moustafa, M.A.; Uchida, T.; et al. Cytochrome P450 gene expression levels in peripheral blood mononuclear cells in comparison with the liver. Cancer Sci. 2004, 95, 520-529. [CrossRef]

4. Wei, C.; Caccavale, R.J.; Kehoe, J.J.; Thomas, P.E.; Iba, M.M. CYP1A2 is expressed along with CYP1A1 in the human lung. Cancer Lett. 2001, 171, 113-120. [CrossRef]

5. Wang, B.; Zhou, S.-F. Synthetic and natural compounds that interact with human cytochrome P450 1A2 and implications in drug development. Curr. Med. Chem. 2009, 16, 4066-4218. [CrossRef] [PubMed]

6. Zhou, S.-F.; Yang, L.-P.; Wei, M.; Duan, W.; Chan, E. Insights into the structure, function, and regulation of human cytochrome P450 1A2. Curr. Drug Metab. 2009, 10, 713-729. [CrossRef] [PubMed]

7. Zhou, S.-F.; Wang, B.; Yang, L.-P.; Liu, J.-P. Structure, function, regulation and polymorphism and the clinical significance of human cytochrome P450 1A2. Drug Metab. Rev. 2010, 42, 268-354. [CrossRef]

8. Jorge-Nebert, L.F.; Jiang, Z.; Chakraborty, R.; Watson, J.; Jin, L.; McGarvey, S.T.; Deka, R.; Nebert, D.W. Analysis of human CYP1A1 and CYP1A2 genes and their shared bidirectional promoter in eight world populations. Hum. Mutat. 2010, 31, 27-40. [CrossRef]

9. Ueda, R.; Iketaki, H.; Nagata, K.; Kimura, S.; Gonzalez, F.J.; Kusano, K.; Yoshimura, T.; Yamazoe, Y. A common regulatory region functions bidirectionally in transcriptional activation of the human CYP1A1 and CYP1A2 genes. Mol. Pharmacol. 2006, 69, 1924-1930. [CrossRef]

10. Klein, K.; Winter, S.; Turpeinen, M.; Schwab, M.; Zanger, U.M. Pathway-targeted pharmacogenomics of CYP1A2 in human liver. Front. Pharmacol. 2010, 1, 129. [CrossRef]

11. Monostory, K.; Pascussi, J.-M.; Kóbori, L.; Dvorak, Z. Hormonal regulation of CYP1A expression. Drug Metab. Rev. 2009, 41, 547-572. [CrossRef]

12. Saruwatari, J.; Nakagawa, K.; Shindo, J.; Tajiri, T.; Fujieda, M.; Yamazaki, H.; Kamataki, T.; Ishizaki, T. A population phenotyping study of three drug-metabolizing enzymes in Kyushu, Japan, with use of the caffeine test. Clin. Pharmacol. Ther. 2002, 72, 200-208. [CrossRef] [PubMed]

13. Guengerich, F.P.; Parikh, A.; Turesky, R.J.; Josephy, P.D. Inter-individual differences in the metabolism of environmental toxicants: Cytochrome P450 1A2 as a prototype. Mutat. Res.-Fundam. Mol. Mech. Mutagen. 1999, 428, 115-124. [CrossRef]

14. Gunes, A.; Dahl, M.-L. Variation in CYP1A2 activity and its clinical implications: Influence of environmental factors and genetic polymorphisms. Pharmacogenomics 2008, 9, 625-637. [CrossRef]

15. Han, X.-M.; Ouyang, D.-S.; Chen, X.-P.; Shu, Y.; Jiang, C.-H.; Tan, Z.-R.; Zhou, H.-H. Inducibility of CYP1A2 by omeprazole in vivo related to the genetic polymorphism of CYP1A2. Br. J. Clin. Pharmacol. 2002, 54, 540-543. [CrossRef] [PubMed]

16. Dobrinas, M.; Cornuz, J.; Oneda, B.; Kohler Serra, M.; Puhl, M.; Eap, C.B. Impact of smoking, smoking cessation, and genetic polymorphisms on CYP1A2 activity and inducibility. Clin. Pharmacol. Ther. 2011, 90, 117-125. [CrossRef] [PubMed]

17. Sachse, C.; Brockmöller, J.; Bauer, S.; Roots, I. Functional significance of a C $\rightarrow$ A polymorphism in intron 1 of the cytochrome P450 CYP1A2 gene tested with caffeine. Br. J. Clin. Pharmacol. 1999, 47, 445-449. [CrossRef] [PubMed]

18. Kootstra-Ros, J.E.; Smallegoor, W.; van der Weide, J. The cytochrome P450 CYP1A2 genetic polymorphisms * $1 F$ and * $1 D$ do not affect clozapine clearance in a group of schizophrenic patients. Ann. Clin. Biochem. Int. J. Lab. Med. 2005, 42, 216-219. [CrossRef]

19. Laika, B.; Leucht, S.; Heres, S.; Schneider, H.; Steimer, W. Pharmacogenetics and olanzapine treatment: $C Y P 1 A 2 * 1 F$ and serotonergic polymorphisms influence therapeutic outcome. Pharm. J. 2010, 10, 20-29. [CrossRef]

20. Ghotbi, R.; Christensen, M.; Roh, H.-K.; Ingelman-Sundberg, M.; Aklillu, E.; Bertilsson, L. Comparisons of CYP1A2 genetic polymorphisms, enzyme activity and the genotype-phenotype relationship in Swedes and Koreans. Eur. J. Clin. Pharmacol. 2007, 63, 537-546. [CrossRef]

21. Na Takuathung, M.; Hanprasertpong, N.; Teekachunhatean, S.; Koonrungsesomboon, N. Impact of CYP1A2 genetic polymorphisms on pharmacokinetics of antipsychotic drugs: A systematic review and meta-analysis. Acta Psychiatr. Scand. 2019, 139, 15-25. [CrossRef] [PubMed]

22. Thorn, C.F.; Aklillu, E.; Klein, T.E.; Altman, R.B. PharmGKB summary: Very important pharmacogene information for CYP1A2. Pharmacogenet. Genomics 2012, 22, 73-77. [CrossRef] [PubMed]

23. Soyama, A.; Saito, Y.; Hanioka, N.; Maekawa, K.; Komamura, K.; Kamakura, S.; Kitakaze, M.; Tomoike, H.; Ueno, K.; Goto, Y.; et al. Single nucleotide polymorphisms and haplotypes of CYP1A2 in a Japanese population. Drug Metab. Pharmacokinet. 2005, 20, 24-33. [CrossRef]

24. Nakajima, M.; Yokoi, T.; Mizutani, M.; Kinoshitah, M.; Funayama, M.; Kamataki, T. Genetic polymorphism in the 5'-flanking region of human CYP1A2 gene: Effect on the CYP1A2 inducibility in humans. J. Biochem. 1999, 125, 803-808. [CrossRef]

25. Djordjevic, N.; Ghotbi, R.; Jankovic, S.; Aklillu, E. Induction of CYP1A2 by heavy coffee consumption is associated with the CYP1A2 -163C>A polymorphism. Eur. J. Clin. Pharmacol. 2010, 66, 697-703. [CrossRef] 
26. Aklillu, E.; Carrillo, J.A.; Makonnen, E.; Hellman, K.; Pitarque, M.; Bertilsson, L.; Ingelman-Sundberg, M. Genetic polymorphism of CYP1A2 in Ethiopians affecting induction and expression: Characterization of novel haplotypes with single-nucleotide polymorphisms in intron 1. Mol. Pharmacol. 2003, 64, 659-669. [CrossRef]

27. Zanger, U.M.; Schwab, M. Cytochrome P450 enzymes in drug metabolism: Regulation of gene expression, enzyme activities, and impact of genetic variation. Pharmacol. Ther. 2013, 138, 103-141. [CrossRef] [PubMed]

28. Tanaka, E. Gender-related differences in pharmacokinetics and their clinical significance. J. Clin. Pharm. Ther. 1999, 24, 339-346. [CrossRef] [PubMed]

29. Parkinson, A.; Mudra, D.R.; Johnson, C.; Dwyer, A.; Carroll, K.M. The effects of gender, age, ethnicity, and liver cirrhosis on cytochrome $\mathrm{P} 450$ enzyme activity in human liver microsomes and inducibility in cultured human hepatocytes. Toxicol. Appl. Pharmacol. 2004, 199, 193-209. [CrossRef]

30. Ou-Yang, D.-S.; Huang, S.-L.; Wang, W.; Xie, H.-G.; Xu, Z.-H.; Shu, Y.; Zhou, H.-H. Phenotypic polymorphism and gender-related differences of CYP1A2 activity in a Chinese population. Br. J. Clin. Pharmacol. 2000, 49, 145-151. [CrossRef]

31. Liu, J.; Lu, Y.-F.; Corton, J.C.; Klaassen, C.D. Expression of cytochrome P450 isozyme transcripts and activities in human livers. Xenobiotica 2021, 51, 279-286. [CrossRef] [PubMed]

32. Denison, M.S.; Nagy, S.R. Activation of the aryl hydrocarbon receptor by structurally diverse exogenous and endogenous chemicals. Annu. Rev. Pharmacol. Toxicol. 2003, 43, 309-334. [CrossRef] [PubMed]

33. Perera, V.; Gross, A.S.; McLachlan, A.J. Influence of environmental and genetic factors on CYP1A2 activity in individuals of South Asian and European ancestry. Clin. Pharmacol. Ther. 2012, 92, 511-519. [CrossRef] [PubMed]

34. Hiemke, C.; Pfuhlmann, B. Interactions and Monitoring of Antipsychotic Drugs. In Handbook of Experimental Pharmacology; Springer: Berlin/Heidelberg, Germany, 2012; Volume 212, pp. 241-265. ISBN 9783642257605.

35. Brewer, L.; Williams, D. Clinically relevant drug-drug and drug-food interactions. Pharmaceut. Med. 2013, 27, 9-23. [CrossRef]

36. Granfors, M.T.; Backman, J.T.; Laitila, J.; Neuvonen, P.J. Oral contraceptives containing ethinyl estradiol and gestodene markedly increase plasma concentrations and effects of tizanidine by inhibiting cytochrome P450 1A2. Clin. Pharmacol. Ther. 2005, 78, 400-411. [CrossRef]

37. Van der Hoeven, T.A.; Coon, M.J. Preparation and properties of partially purified cytochrome P-450 and reduced nicotinamide adenine dinucleotide phosphate-cytochrome P-450 reductase from rabbit liver microsomes. J. Biol. Chem. 1974, 249, 6302-6310. [CrossRef]

38. Lowry, O.H.; Rosebrough, N.J.; Farr, A.L.; Randall, R.J. Protein measurement with the Folin phenol reagent. J. Biol. Chem. 1951, 193, 265-275. [CrossRef]

39. Butler, M.A.; Iwasaki, M.; Guengerich, F.P.; Kadlubar, F.F. Human cytochrome P-450PA (P-450IA2), the phenacetin O-deethylase, is primarily responsible for the hepatic 3-demethylation of caffeine and N-oxidation of carcinogenic arylamines. Proc. Natl. Acad. Sci. USA 1989, 86, 7696-7700. [CrossRef]

40. Déri, M.T.; Kiss, Á.F.; Tóth, K.; Paulik, J.; Sárváry, E.; Kóbori, L.; Monostory, K. End-stage renal disease reduces the expression of drug-metabolizing cytochrome P450s. Pharmacol. Rep. 2020, 72, 1695-1705. [CrossRef]

41. Stephens, M.; Smith, N.J.; Donnelly, P. A new statistical method for haplotype reconstruction from population data. Am. J. Hum. Genet. 2001, 68, 978-989. [CrossRef]

42. Stephens, M.; Scheet, P. Accounting for decay of linkage disequilibrium in haplotype inference and missing-data imputation. Am. J. Hum. Genet. 2005, 76, 449-462. [CrossRef] [PubMed]

43. Chevalier, D.; Cauffiez, C.; Allorge, D.; Lo-Guidice, J.M.; Lhermitte, M.; Lafitte, J.J.; Broly, F. Five novel natural allelic variants951A >C, 1042G > A (D348N), 1156A > T (I386F), 1217G >A (C406Y) and 1291C > T (C431Y)—of the human CYP1A2 gene in a French Caucasian population. Hum. Mutat. 2001, 17, 355. [CrossRef] [PubMed]

44. Perera, V.; Gross, A.S.; Polasek, T.M.; Qin, Y.; Rao, G.; Forrest, A.; Xu, J.; McLachlan, A.J. Considering CYP1A2 phenotype and genotype for optimizing the dose of olanzapine in the management of schizophrenia. Expert Opin. Drug Metab. Toxicol. 2013, 9, 1115-1137. [CrossRef] [PubMed]

45. Temesvári, M.; Kóbori, L.; Paulik, J.; Saŕvaŕy, E.; Belic, A.; Monostory, K. Estimation of drug-metabolizing capacity by cytochrome P450 genotyping and expression. J. Pharmacol. Exp. Ther. 2012, 341, 294-305. [CrossRef]

46. Chung, W.G.; Kang, J.H.; Park, C.S.; Cho, M.H.; Cha, Y.N. Effect of age and smoking on in vivo CYP1A2, flavin-containing monooxygenase, and xanthine oxidase activities in Koreans: Determination by caffeine metabolism. Clin. Pharmacol. Ther. 2000, 67, 258-266. [CrossRef]

47. Granfors, M.T.; Backman, J.T.; Neuvonen, M.; Neuvonen, P.J. Ciprofloxacin greatly increases concentrations and hypotensive effect of tizanidine by inhibiting its cytochrome P450 1A2-mediated presystemic metabolism. Clin. Pharmacol. Ther. 2004, 76, 598-606. [CrossRef]

48. Ayano, G. Psychotropic medications metabolized by cytochromes P450 (CYP) 2D6 enzyme and relevant drug interactions. Clin. Pharmacol. Biopharm. 2016, 5, 2-5. [CrossRef]

49. Nehlig, A. Interindividual differences in caffeine metabolism and factors driving caffeine consumption. Pharmacol. Rev. 2018, 70, 384-411. [CrossRef]

50. Koonrungsesomboon, N.; Khatsri, R.; Wongchompoo, P.; Teekachunhatean, S. The impact of genetic polymorphisms on CYP1A2 activity in humans: A systematic review and meta-analysis. Pharm. J. 2018, 18, 760-768. [CrossRef] 
51. Ing Lorenzini, K.; Desmeules, J.; Rollason, V.; Bertin, S.; Besson, M.; Daali, Y.; Samer, C.F. CYP450 genotype-Phenotype concordance using the geneva micrococktail in a clinical setting. Front. Pharmacol. 2021, 12, 730637. [CrossRef]

52. Rodríguez-Antona, C.; Donato, M.T.; Pareja, E.; Gómez-Lechón, M.-J.; Castell, J.V. Cytochrome P-450 mRNA expression in human liver and its relationship with enzyme activity. Arch. Biochem. Biophys. 2001, 393, 308-315. [CrossRef] [PubMed]

53. Sachse, C.; Bhambra, U.; Smith, G.; Lightfoot, T.J.; Barrett, J.H.; Scollay, J.; Garner, R.C.; Boobis, A.R.; Wolf, C.R.; Gooderham, N.J. Polymorphisms in the cytochrome P450 CYP1A2 gene (CYP1A2) in colorectal cancer patients and controls: Allele frequencies, linkage disequilibrium and influence on caffeine metabolism. Br. J. Clin. Pharmacol. 2003, 55, 68-76. [CrossRef] [PubMed]

54. Skarke, C.; Kirchhof, A.; Geisslinger, G.; Lötsch, J. Rapid genotyping for relevant CYP1A2 alleles by pyrosequencing. Eur. J. Clin. Pharmacol. 2005, 61, 887-892. [CrossRef] [PubMed]

55. Pavanello, S.; Pulliero, A.; Lupi, S.; Gregorio, P.; Clonfero, E. Influence of the genetic polymorphism in the $5^{\prime}$-noncoding region of the CYP1A2 gene on CYP1A2 phenotype and urinary mutagenicity in smokers. Mutat. Res.-Genet. Toxicol. Environ. Mutagen. 2005, 587, 59-66. [CrossRef]

56. Pavanello, S.; Fedeli, U.; Mastrangelo, G.; Rota, F.; Overvad, K.; Raaschou-Nielsen, O.; Tjønneland, A.; Vogel, U. Role of CYP1A2 polymorphisms on lung cancer risk in a prospective study. Cancer Genet. 2012, 205, 278-284. [CrossRef]

57. Caudle, K.; Klein, T.; Hoffman, J.; Muller, D.; Whirl-Carrillo, M.; Gong, L.; McDonagh, E.; Sangkuhl, K.; Thorn, C.; Schwab, M.; et al. Incorporation of pharmacogenomics into routine clinical practice: The Clinical Pharmacogenetics Implementation Consortium (CPIC) guideline development process. Curr. Drug Metab. 2014, 15, 209-217. [CrossRef]

58. Zhou, Y.; Ingelman-Sundberg, M.; Lauschke, V.M. Worldwide distribution of cytochrome P450 alleles: A meta-analysis of population-scale sequencing projects. Clin. Pharmacol. Ther. 2017, 102, 688-700. [CrossRef]

59. Van der Wouden, C.; Cambon-Thomsen, A.; Cecchin, E.; Cheung, K.; Dávila-Fajardo, C.; Deneer, V.; Dolžan, V.; IngelmanSundberg, M.; Jönsson, S.; Karlsson, M.; et al. Implementing pharmacogenomics in Europe: Design and implementation strategy of the Ubiquitous Pharmacogenomics Consortium. Clin. Pharmacol. Ther. 2017, 101, 341-358. [CrossRef]

60. Swen, J.J.; Nijenhuis, M.; van Rhenen, M.; de Boer-Veger, N.J.; Buunk, A.M.; Houwink, E.J.F.; Mulder, H.; Rongen, G.A.; van Schaik, R.H.N.; van der Weide, J.; et al. Pharmacogenetic information in clinical guidelines: The European perspective. Clin. Pharmacol. Ther. 2018, 103, 795-801. [CrossRef]

61. Ruan, C.-J.; de Leon, J. Is there a future for CYP1A2 pharmacogenetics in the optimal dosing of clozapine? Pharmacogenomics 2020, 21,369-373. [CrossRef]

62. Tian, D.-D.; Natesan, S.; White, J.R.; Paine, M.F. Effects of common CYP1A2 genotypes and other key factors on intraindividual variation in the caffeine metabolic ratio: An exploratory analysis. Clin. Transl. Sci. 2019, 12, 39-46. [CrossRef] [PubMed]

63. Ceni, E.; Mello, T.; Galli, A. Pathogenesis of alcoholic liver disease: Role of oxidative metabolism. World J. Gastroenterol. 2014, 20, 17756-17772. [CrossRef]

64. Lown, K.; Kolars, J.; Turgeon, K.; Merion, R.; Wrighton, S.A.; Watkins, P.B. The erythromycin breath test selectively measures P450IIIA in patients with severe liver disease. Clin. Pharmacol. Ther. 1992, 51, 229-238. [CrossRef]

65. Seitz, H.K.; Mueller, S. Alcoholic Liver Disease. In Clinical Hepatology; Springer: Berlin/Heidelberg, Germany, 2010; Volume 2, pp. 1111-1151. ISBN 978-3-642-04509-7.

66. Fontana, R.J.; Shakil, A.O.; Greenson, J.K.; Boyd, I.; Lee, W.M. Acute liver failure due to amoxicillin and amoxicillin/clavulanate. Dig. Dis. Sci. 2005, 50, 1785-1790. [CrossRef] [PubMed]

67. Gresser, U. Amoxicillin-clavulanic acid therapy may be associated with severe side effects-Review of the literature. Eur. J. Med. Res. 2001, 6, 139-149.

68. Fekete, F.; Mangó, K.; Déri, M.; Incze, E.; Minus, A.; Monostory, K. Impact of genetic and non-genetic factors on hepatic CYP2C9 expression and activity in Hungarian subjects. Sci. Rep. 2021, 11, 17081. [CrossRef]

69. Kiss, Á.F.; Vaskó, D.; Déri, M.T.; Tóth, K.; Monostory, K. Combination of CYP2C19 genotype with non-genetic factors evoking phenoconversion improves phenotype prediction. Pharmacol. Rep. 2018, 70, 525-532. [CrossRef]

70. Meyer, J.M. Individual changes in clozapine levels after smoking cessation: Results and a predictive model. J. Clin. Psychopharmacol. 2001, 21, 569-574. [CrossRef]

71. Carrillo, J.A.; Herráiz, A.G.; Ramos, S.I.; Gervasini, G.; Vizcaíno, S.; Benítez, J. Role of the smoking-induced cytochrome P450 (CYP)1A2 and polymorphic CYP2D6 in steady-state concentration of olanzapine. J. Clin. Psychopharmacol. 2003, 23, 119-127. [CrossRef] [PubMed]

72. Lucas, R.A.; Gilfillan, D.J.; Bergstrom, R.F. A pharmacokinetic interaction between carbamazepine and olanzapine: Observations on possible mechanism. Eur. J. Clin. Pharmacol. 1998, 54, 639-643. [CrossRef] [PubMed]

73. Zhou, S.-F.; Yang, L.-P.; Zhou, Z.-W.; Liu, Y.-H.; Chan, E. Insights into the substrate specificity, inhibitors, regulation, and polymorphisms and the clinical impact of human cytochrome P450 1A2. AAPS J. 2009, 11, 481-494. [CrossRef] [PubMed] 